Journal of Educational

and Psychological Sciences

Volume (5), Issue (39): 30 Oct 2021

P: 138 - 158

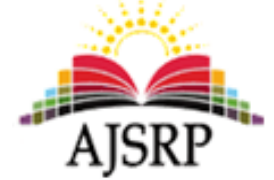

ISSN: 2522- 3399
مجلة العلوم

التربوية والنفسية

المجلد (5)، العدد (39): 30 أكتوبر 2021 م

ص: 138 - 158

\title{
Proposed Perceptions to address reading impairment of Middle School Students from the point of view of their Teachers in Government Schools in the State of Kuwait
}

\section{Bandar Manshed Mohammad Aldhafeeri}

Ministry of Education || State of Kuwait

\begin{abstract}
The aim of the research is to identify the proposed perceptions to address poor reading among middle school students from the point of view of their teachers and teachers in public schools in Kuwait, and the research sample consisted of (350) teachers, selected in the random class way from middle school teachers in The 512 ، 2 public education schools in Mubarak al- Kabir governorate) Kuwait (were adopted, and the analytical descriptive curriculum was adopted, and the questionnaire was adopted as a data collection tool consisting of (32) paragraphs spread over three integrated fields as follows :Proposed perceptions to address poor reading related to the role (family and teacher, technical guidance and school curriculum, school and major educational institution).

The research resulted in a series of results, the most important of which is that the degree of appreciation of middle school teachers for the proposed perceptions to address poor reading among middle school students in all its integrated areas came to a large extent, the most important of which is the provision of a scientific and cultural stock among the teacher qualifies him to address the reading weakness of students, take into account the family's various problems and stand with him to overcome them, provide modern educational and technological means in the school, provide the major educational institution for all ways to address the problems of students, especially reading weakness, monitor guidance Technical commitment of teachers to the treatment plans provided to students, in addition to the existence of statistically significant differences between the responses of the members of the study sample towards the proposed perceptions to address poor reading in middle school students from the point of view of their teachers and teachers in public schools in Kuwait at all fields and the tool as a whole due to the sex change and the differences came in favor of male teachers.

In the light of the results the research made a number of recommendations, the most important of which Taking into account the importance of the diagnostic calendar for students at the beginning of the year and semester, and educating teachers and following them up by their supervisors through regular visits to them during the academic year to identify the weaknesses and strengths of each student, and qualify and prepare Arabic teachers through training courses on addressing poor reading among students .
\end{abstract}

Keywords: Perceptions, treatment of poor reading, middle school students, teachers of public schools, State of Kuwait.

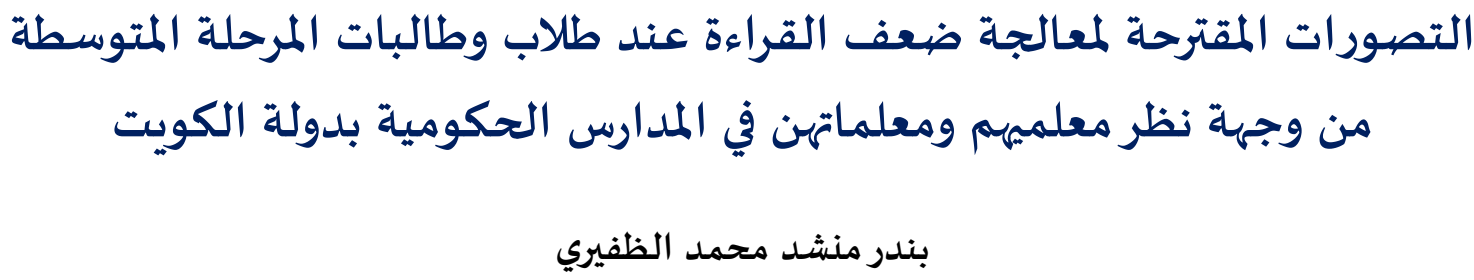


وزارة التربية || دولة الكويت

المستخلص: هدف البحث إلى التعرف على التصورات المقترحة لمعالجة ضعف القراءة عند طلاب المرحلة المتوسطة من وجهة نظر

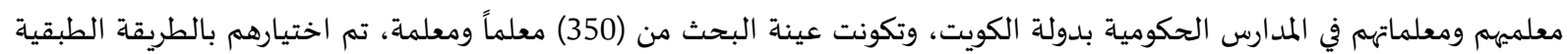
العشوائية من معلمي ومعلمات المرحلة المتوسطة في مدارس التعليم العام بمحافظة مبارك الكبير (دولة الكويت)، والبالغ عددهم

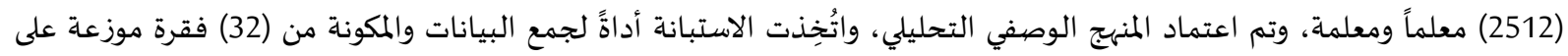
ثلاثة مجالات مدمجة على النحو التالي: التصورات المقترحة لمعالجة ضعف اعتمادة القراءة المتعلقة بدور (الأسرة والمعلم، التوجيه الفني والمنهج

المدرسي، المدرسة والمؤسسة التعليمية الكبرى). أسفر البحث عن مجموعة من النتائج أهمها: أن درجة تقدير معلمي ومعلمات المرحلة المتوسطة لموسية للتصيورات المقترحة لمعالجة ضعف

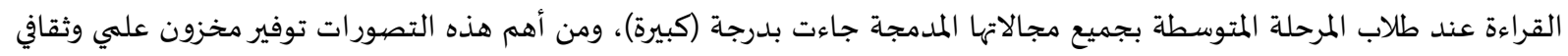

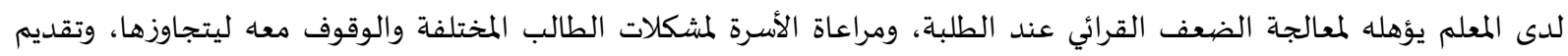

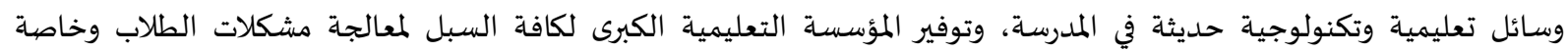

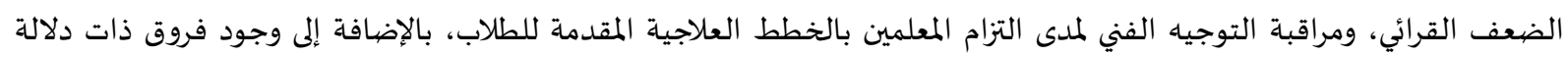

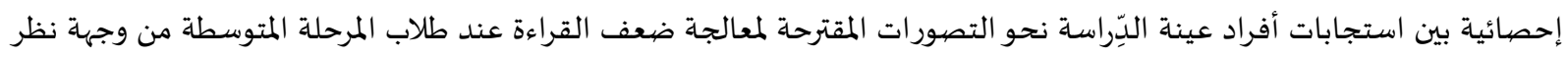

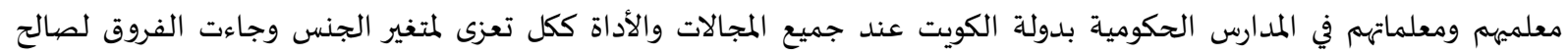
المعلمين الذكور.

وفي ضوء النتائج قدم البحث عدد من التوصيات أهمها: الأخذ بعين الاعتبار أهمية التقويم التشخيصي للطلبة بداية العام والفصل

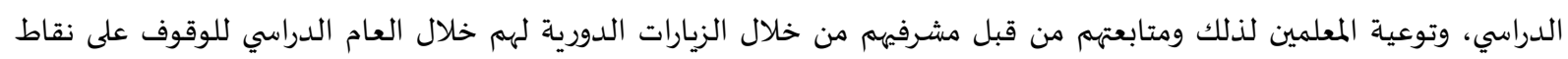

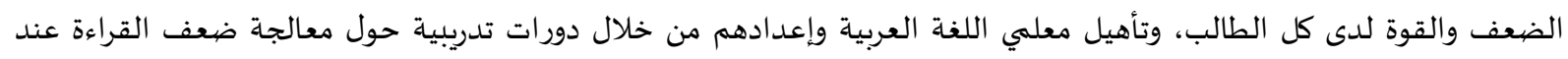

الطلبة.

الكلمات المفتاحية: التصورات، معالجة ضعف القراءة، طلاب وطالبات المرحلة المتوسطة، معلمي ومعلمات المدارس الحكومية، دولة الكويت.

مقدمة.

القراءة مهارة سامية وعظيمة ولازمة للإنسان أمر الله بها ليتعلمها الإنسان ويتقنها لما لها من مكانة عظيمة وقيّمة، إلى جانب أنها سبب رئيس ومههم لنموه نمواً شامل متكاملاً، ولأها نافذة حقيقية للمعرفة والإدراك، ودلالة

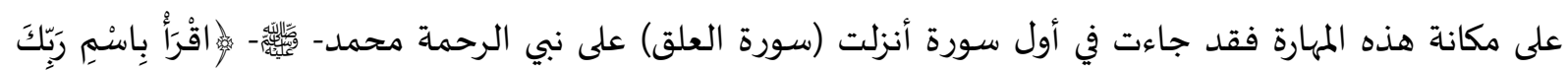

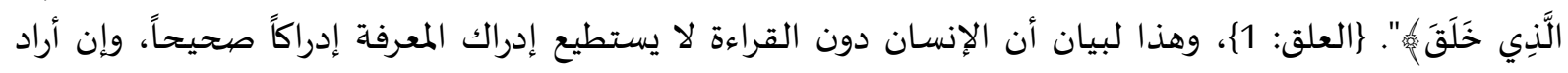

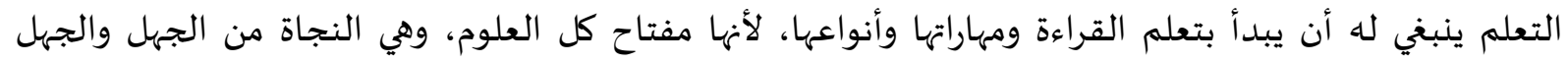
المركب، فمدارك العقل تعمل وفقها، فهيَ تتسع وتنمو وتتفتح كما تتفتح الأزهار لتستنشق تلك الحياة الجميلة، والقراءة لا تقف عند كونها وسيلة تعلم أصيلة وأسـاسية، بل تعتبر وسيلة تواصل أبدية ملازمة لله يتعلم من خلالها ويتواصل بينه وبين الآخر، ذلك التواصل المثمر، والمستدام بين العقول والأفكار والرؤى ووجهات النظر، بل حتى

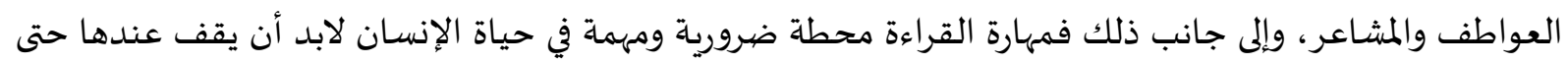
يتقنها ليستثمر فيها ويكتسب الخبرات المتعددة ويتشرب منها تجارب من سبقه بدءاً من طفولته وهي الفترة المهمة لاكتساب ذلك الكم المناسب من المعرفة الذي يؤهله ليشق طريقه بعد ذلك للتعلم بامتلاكه للمفتاح الحقيقي للمعرفة ( القراءة ).

يعيش العالم اليوم فارق كبير مما كان موجودًا سابقًا في العصور الماضية، حيث من أبرز المصطلحات

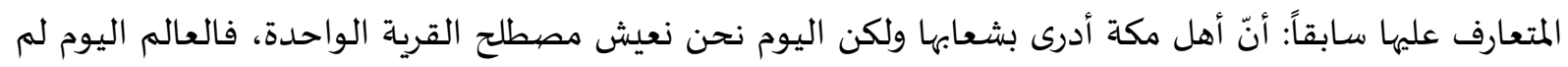
يعد ذلك الكون الفسيح المستحيل على الإنسان التجول فياه، والذي قد يجد فياه الإنسان تلك الصعوبة لمعرفة 
أخبار من حوله في البلدان المجاورة، ناهيك عن البعيدة عن القارة، وتفاصيل معيشتهم أو ما توصل إليه العلماء في

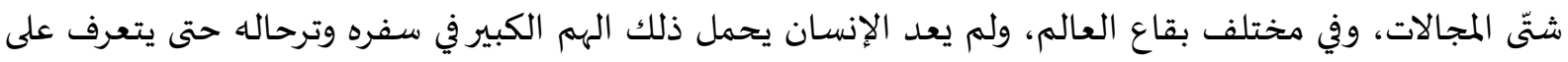

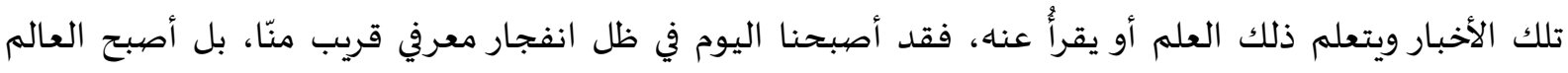

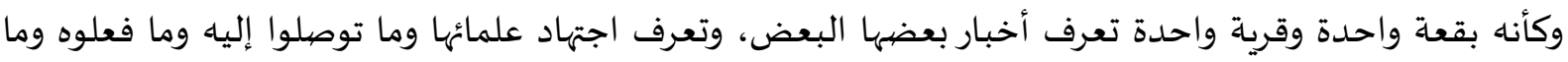

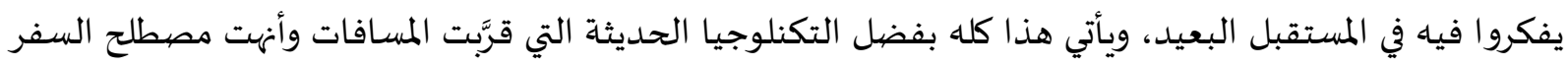

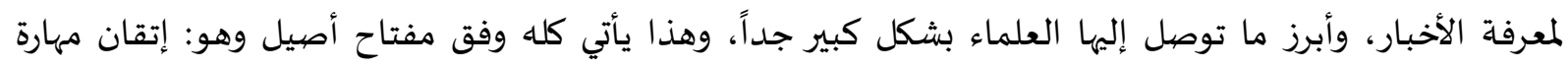

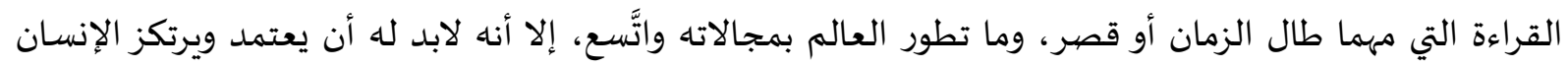

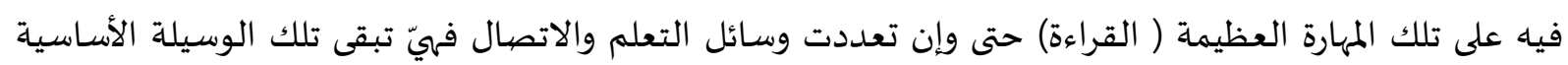

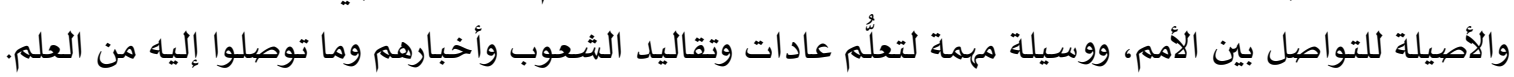

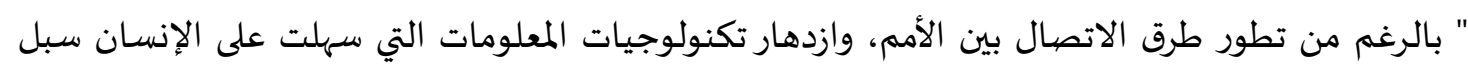

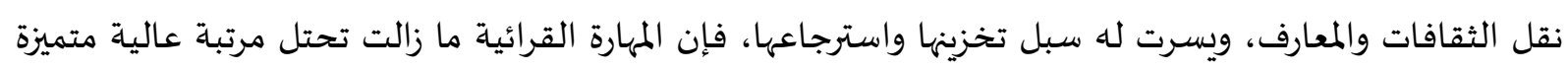

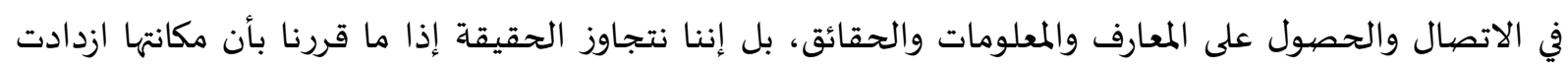

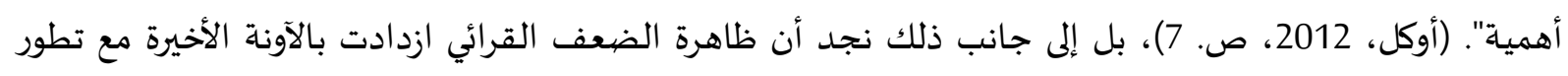

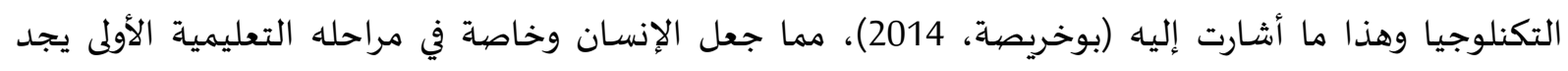

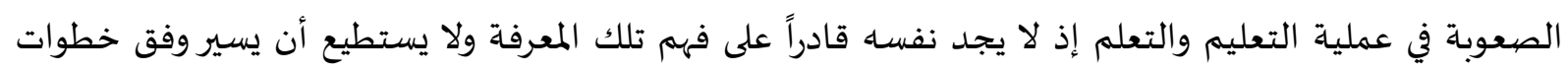

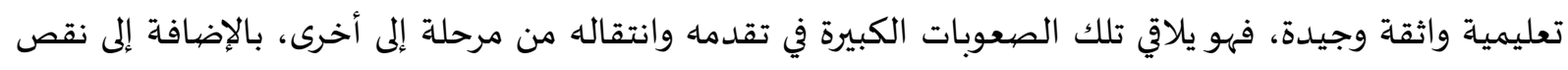

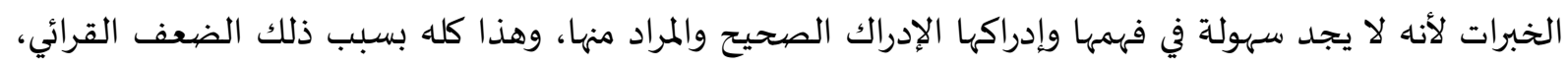

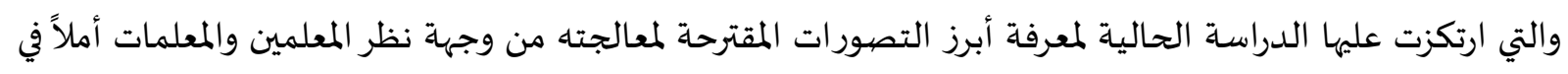

تجاوز تلك المعضلة المهمة.

مشكلة البحث:

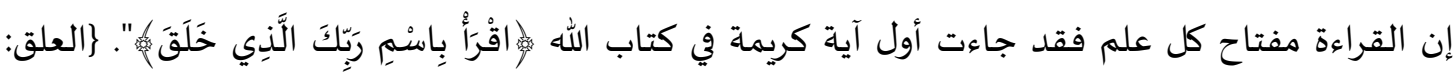

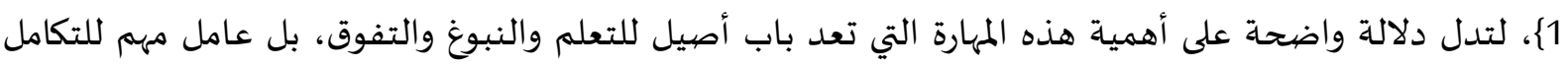

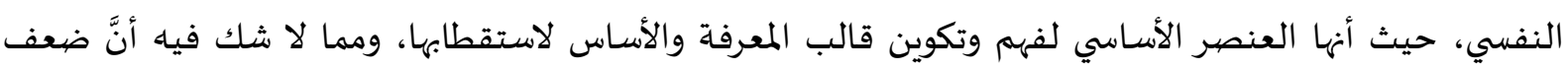
القراءة هو عامل كبير ومؤثر كافي لإلحاق الضرر بصاحباه في التعلم، وعقبة كبيرة أمام الاستمرار بعملية التعليم

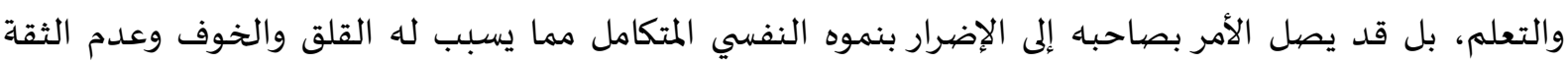

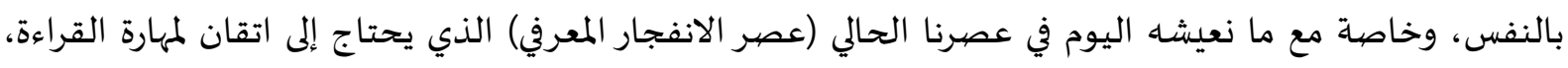

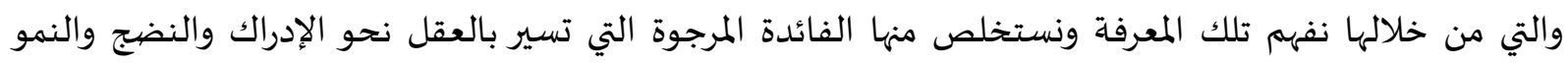

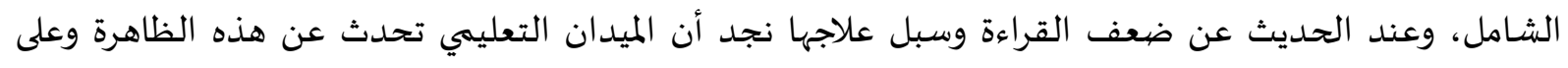

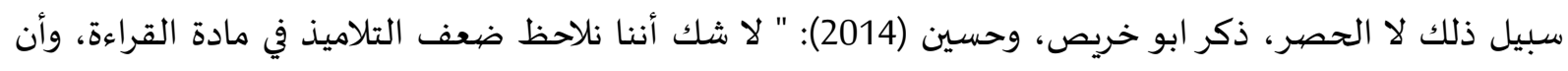

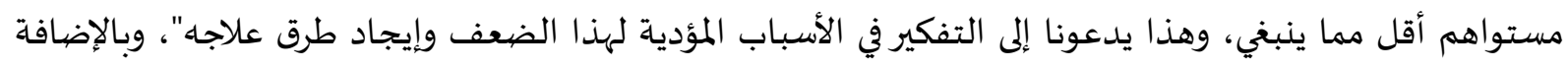

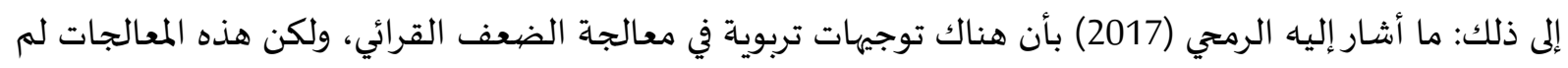

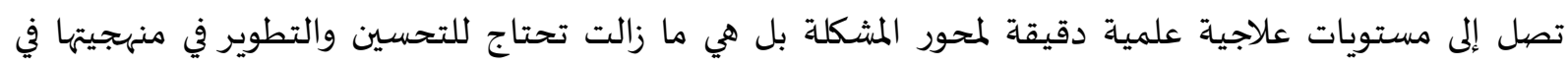
معالجة مشكلة ضعف القراءة لدى طلاب المراحل التعليمية المختلفة. 
ومن هنا تحددت مشكلة البحث في التعرف على التصورات المقترحة لمعالجة ضعف القراءة عند طلاب وطالبات المرحلة المتوسطة من وجهة نظر معلميهم ومعلماتهم في المدارس الحكومية بدولة الكويت.

أسئلة البحث

تتحدد مشكلة البحث الحالي في الأسئلة التالية: 1- ما التصورات المقترحة لمعالجة ضعف القراءة عند طلاب وطالبات المرحلة المتوسطة المتعلقة بدور الأسرة والمعلم من وجهة نظر معلميهم ومعلماتهم في المدارس الحكومية بدولة الكويت؟ 2- ما التصورات المقترحة لمعالجة ضعف القراءة عند طلاب وطالبات المرحلة المتوسطة المتعلقة بدور التوجيه

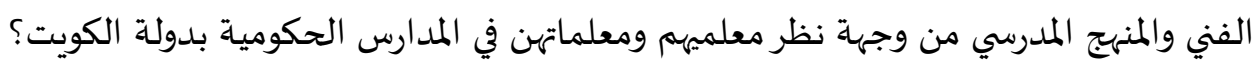

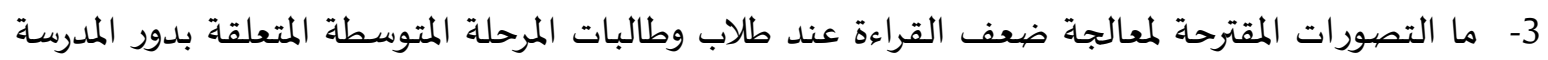
والمؤسسة التعليمية الكبرى من وجهة نظر معلميهم ومعلماتهن في المدارس الحكومية بدولة الكويت؟

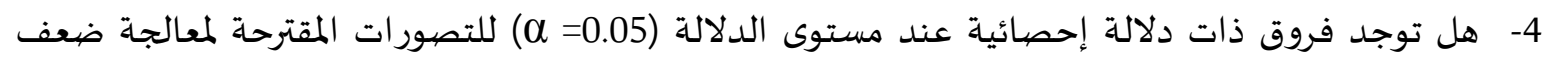

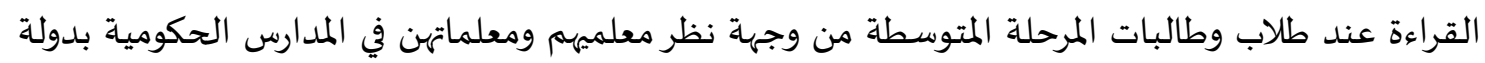
الكويت تُعزى لمتغير الجنس (ذكر / أنثى)؟

$$
\text { أهداف البحث }
$$
1- التعرف على التصورات المقترحة لمعالجة ضعف القراءة عند طلاب وطالبات المرحلة المتوسطة المتعلقة بدور

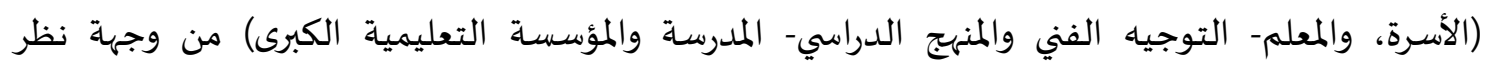
معلميهم ومعلماتهن في المدارس الحكومياة بدولة الكويت. 2- الكشف عن الفروق ذات الدلالة الإحصائية للتصورات المقترحة لمعالجة الضعف القرائي عند طلاب

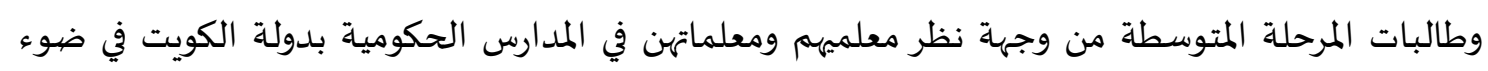
متغير الجنس.

تكمن أهمية الدراسة في تعريف المعلمين التصورات المقترحة لمعالجة ضعف القراءة عند طلاب وطالبات

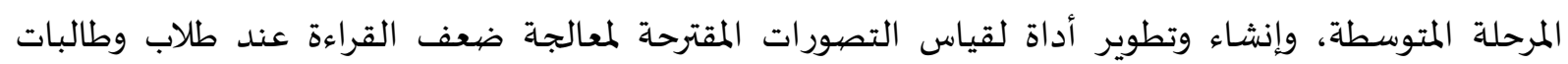

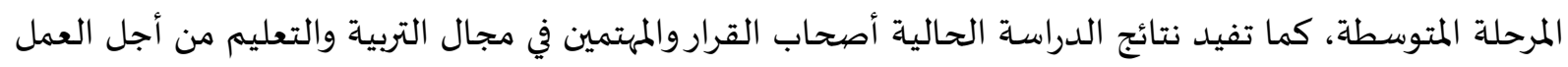

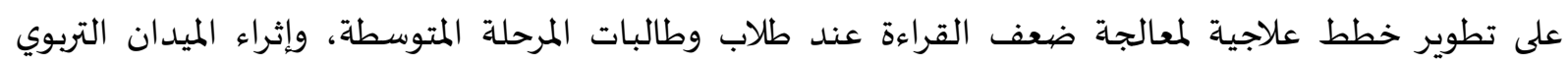

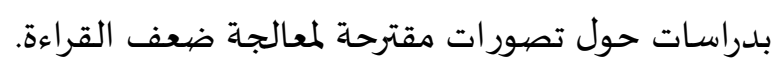

اقتصر البحث على الحدود التالية:

الحدود الموضيوعية: ارتكز البحث على معرفة التصورات المقترحة لمعالجة ضعف المبه القراءة.

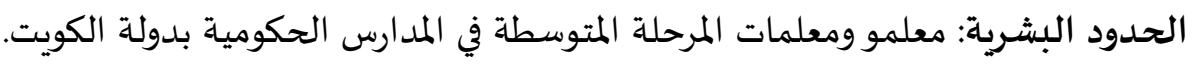

الحدود المكانية: اقتصر البحث على منطقة مبارك الكبير التعليمية في دولة الكويت. 
• الحدود الزمانية: طُبق البحث في الفصل الدراسي الثاني للعام الدراسي 2021/2020م.

$$
\text { مصطلحات البحث }
$$

- القراءة إجرائياً: مهارة يتعلمها طلاب وطالبات المرحلة المتوسطة تمكنهم من نطق الحروف والكلمات والجمل

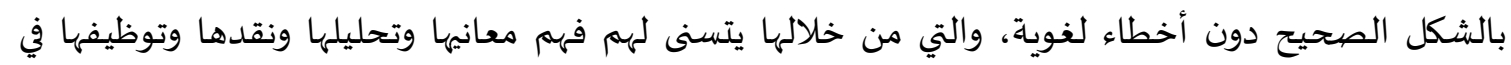

$$
\text { شتىّ مجالات الحياة. }
$$

- ضعف القراءة إجرائياً: افتقار طلاب وطالبات المرحلة المتوسطة لكيفية نطق الحروف والكلمات والجمل بالشكل الصحيح، وإيجاد صعوبة في إتقانها، مما يجعلهم غير قادرين على فهم معانها وإنها: والمراد منها وتوظيفها بالشكل الأمثل في شتّى مجالات الحياة. - المرحلة المتوسطة: هي: " حلقة وسطى بين التعليم الابتدائي من جهاة، والتعليم الثانوي من جهة أخرى، فهي التهاة

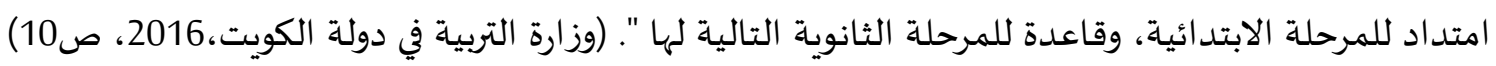

2. الإطار النظري والدراسـات السابقة. أولاًا - الإطار النظري.

مفهوم القراءة:

مرَّ مصطلح القراءة بعدة تعريفات ضيقة وواسعة، فمنها ما تناول القراءة على أنها وسيلة ومهارة للاتصال

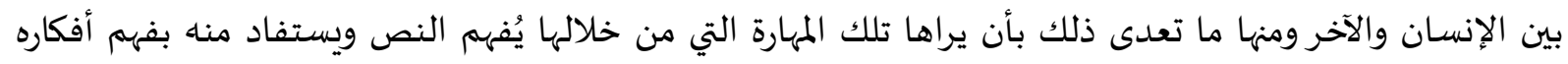

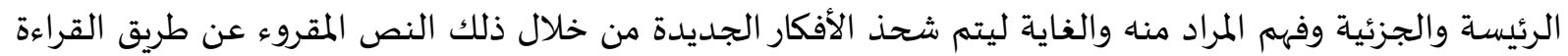
وتوريدها للشعوب وفيما يلي سيتم تناول مفهوم القراءة لغوياً واصطلاحياً:

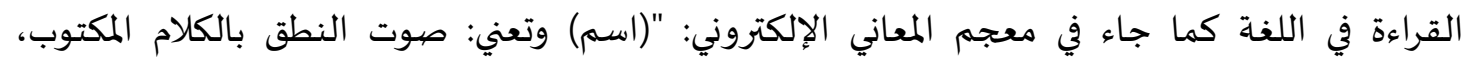

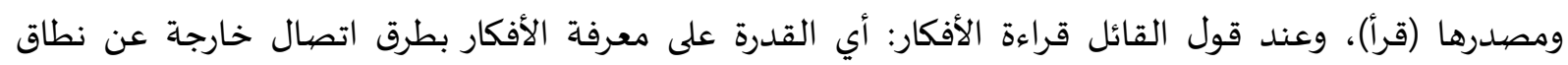

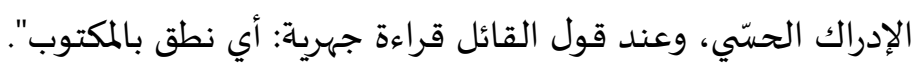
وأما في الاصطلاح فتعددت المفاهيم، بين المعنى الضيق والواسع، حيث عرفها فئها عطية (2007) بأها: عملية

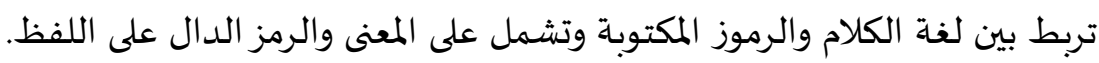

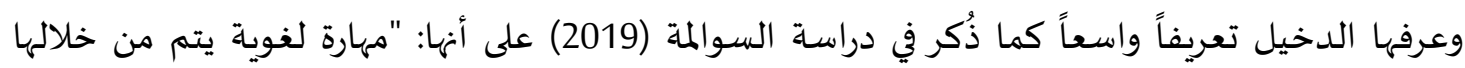

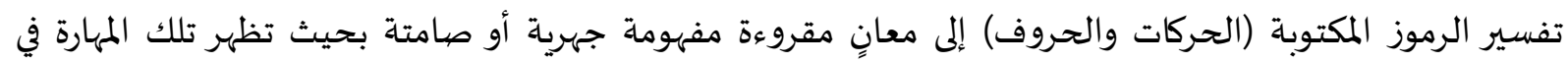

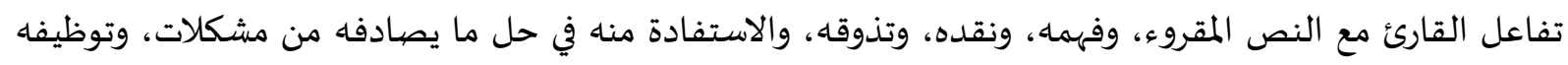

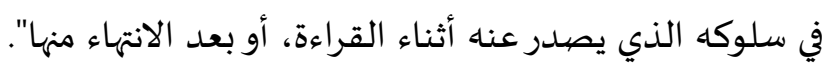

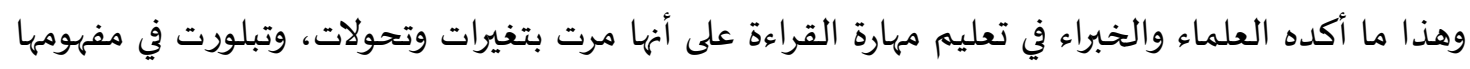

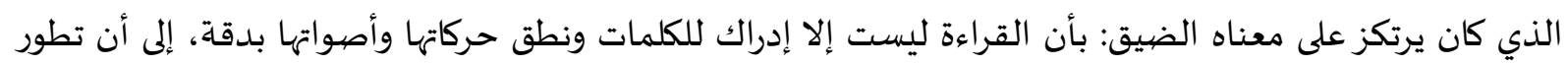

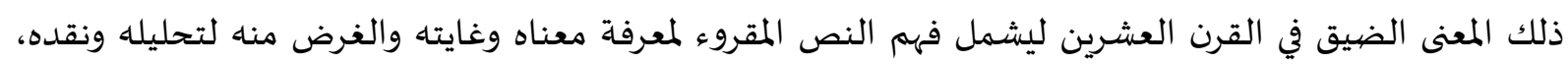

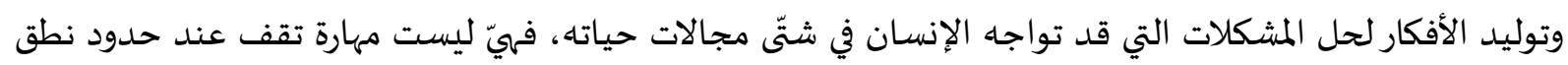

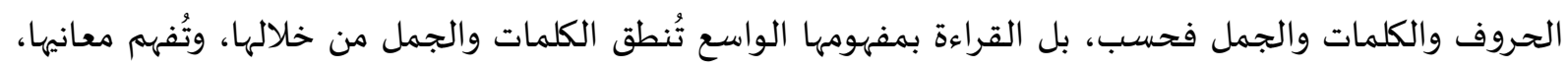


وتتضح عن طريقها الأفكار والغايات والأغراض، وتتبين المعاني وتُدرَك، كي تصل لعقل القارئ، ومع هذه القراءة يتم

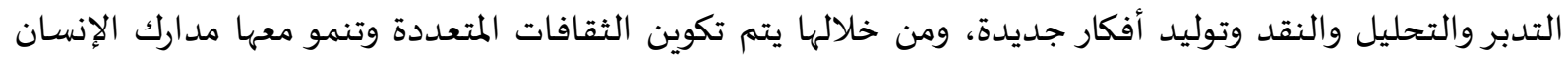
وتنضج بها مناطق العقل لتسير بالإنسان لذلك النمو الشامل المتكامل.

ثانياً: أهمية القراءة

بالقراءة يفهم المرء ما يجول من حوله وبالقراءة يكتسب المرء معرفته بالأشياء، فهي ليست الأداة الوحيدة

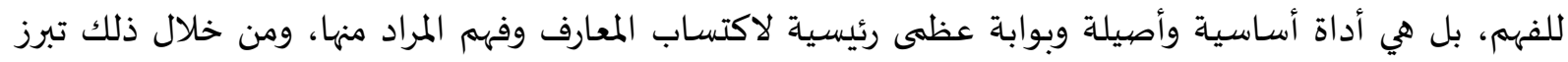
أهميتها عند الإنسان بدءاً منذ طفولته إلى أن يرحل من هذه الحياة، فمعها يتعلم ويتعرف على كل ماده مادة علميلة

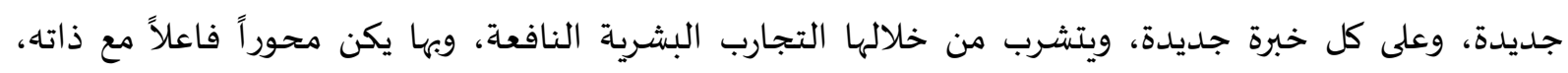

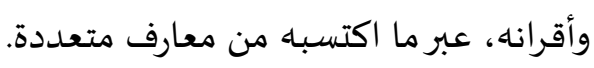

إنّ القراءة وسيلة تواصل وتعلم أساسية ولازمة خالدة مع الإنسان في هذه الحيان الحياة إلى أن يرحل منها مهما

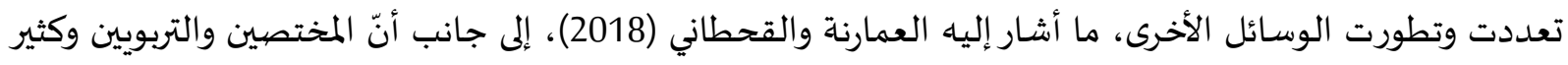

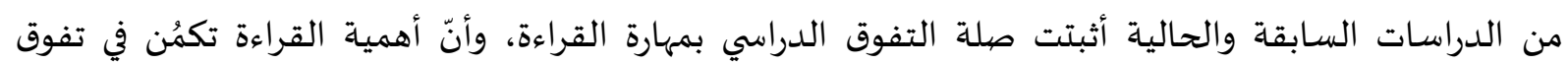

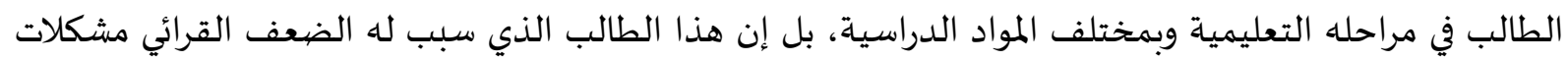

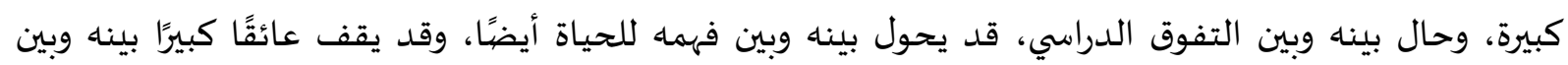

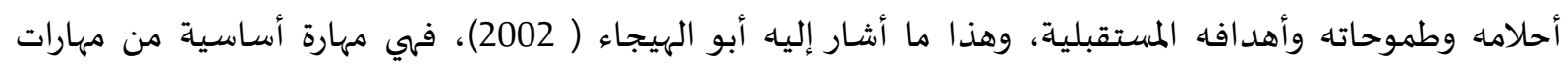

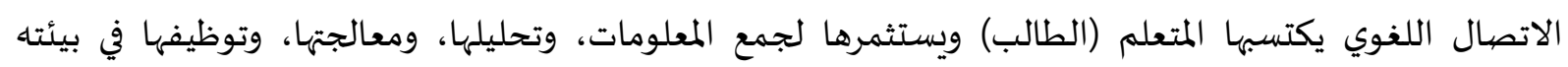

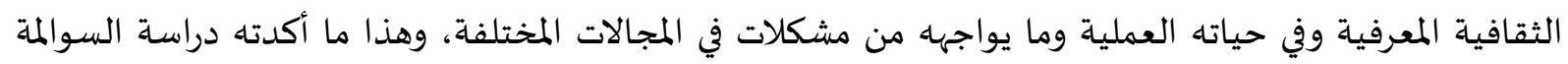

تكمُن أهمية القراءة بكونها مادة وقائية تقف أمام عدم قدرة الطالب على التحصيل الدراسي العالي، بل هي

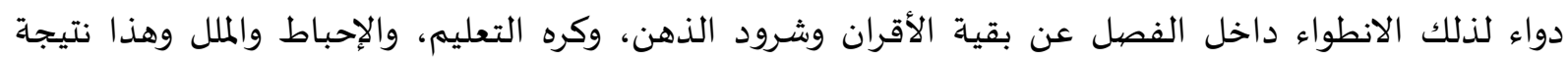

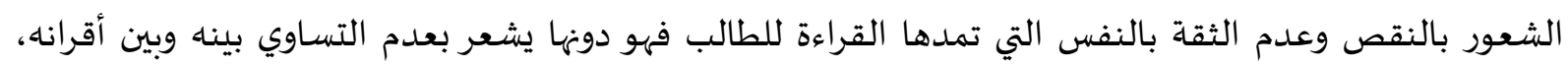

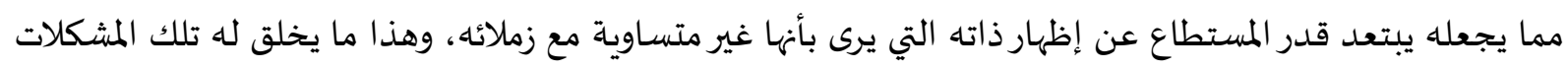

النفسية السابقة، أشارت إليه دراسـة القرعان (2018).

ثالثاً: أنواع القراءة

تنقسم القراءة من حيث الأداء والتجسيد لقسمين مهمّين هما:

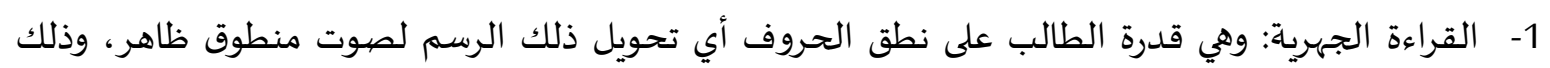

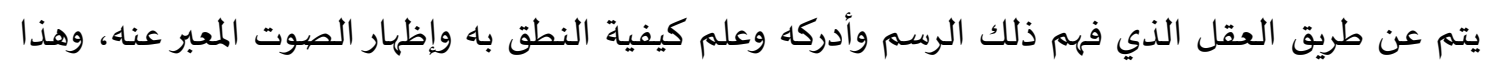
ما يلاحظه المعلم ويفرق به بين طلابه، بين طالب حقق تلك المهارة بجودة عالية وبين طالب واجه معضله فيلة

تفسير ذلك الرسم وتحويله لصوت منطوق ظاهر صحيح، ودون أخطاء تؤثر على فهمه للمكت للمكتوب.

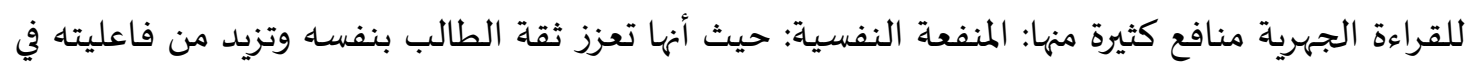

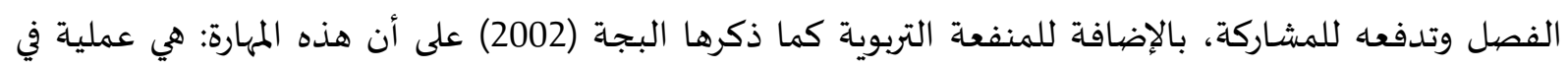
أساسها تشخيصية للعلاج من خلالها يتم تقويم الطالب وتمييزه وإعادة تأهيله ليكون ملازماً ومساوياً لأقرانه.

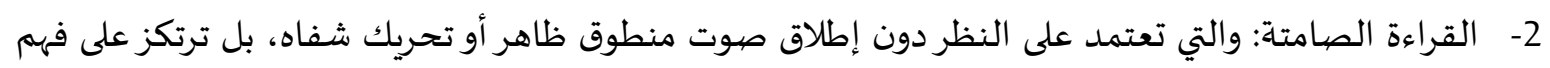

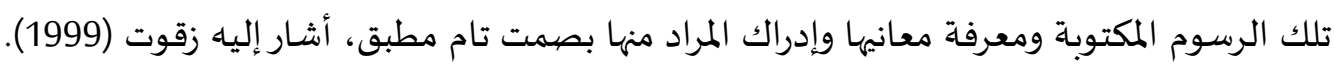


للقراءة الصامتة مزايا متعددة منها: أنها تجعل الطالب يركز باهتمامه على المعنى مما يجعله يأخذ وقت أقل

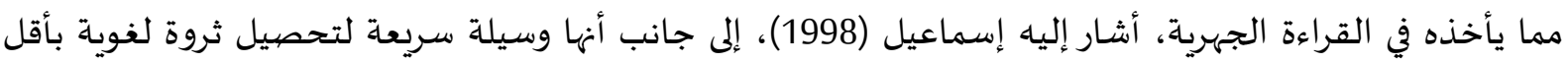

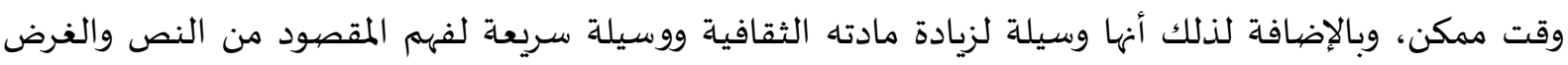

رابعاً: فوائد ومنافع القراءة

تعددت فوائد ومنافع القراءة حيث تُعد وسيلة أساسية للاتصال بين الإنسان والآخر، ومصددر أساسي

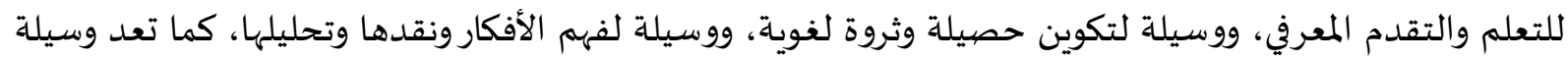

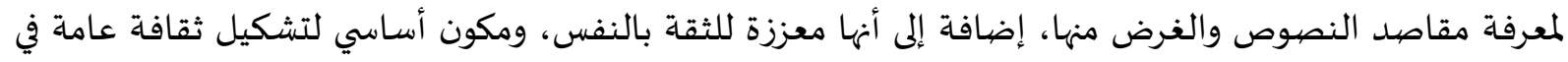
شتّى المجالات، وأساس في تقدم الطالب في التحصيل الدراسي وسبب أصيل لتفوقه الدراسي، وأكّدَ ذلك عابد إندان

وأشار رقاني (2017) إلى أن القراءة تحقق المتعة وتقضي على وقت الفراغ وبهذا يُصبح الإنسان سعيدًا في

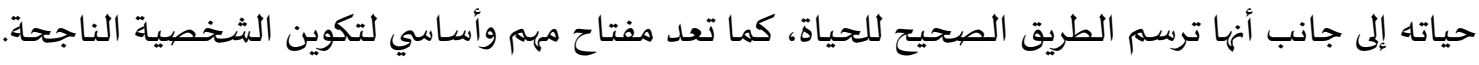

خامساً: أسباب الضعف القرائي

بالرغم من الانفجار المعرفي وتطور تكنلوجيا التعليم، ووسائل التعليم الحديثة وتعدد طرق التدريس

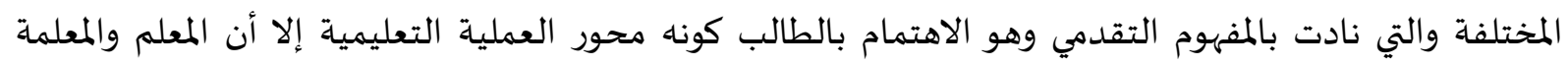

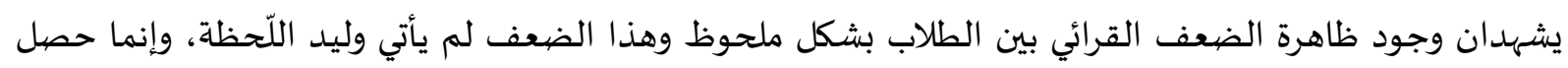

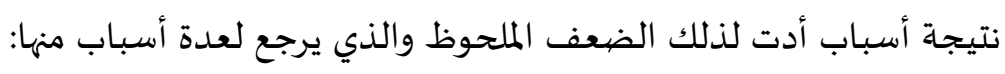

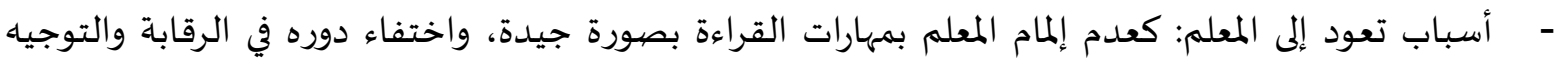
على المتعلمين، وقلة اهتمامه وعدم قدرته على تشخيص العيوب القرائية وصعوبتها، وفقدان المعان حافز التعليم

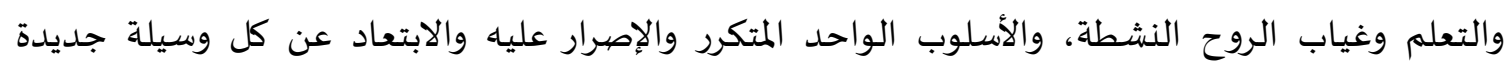
للتعليم (إسماعيل، فرج، 2019).

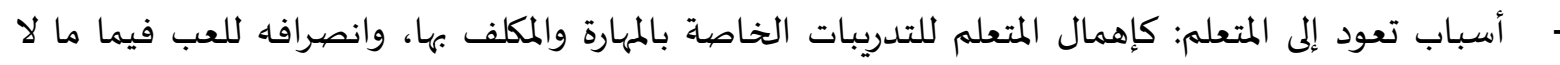

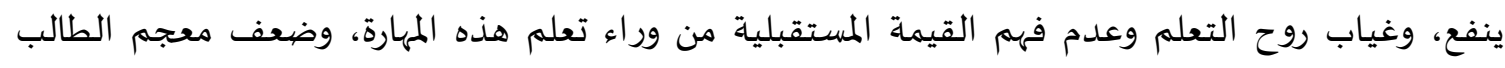

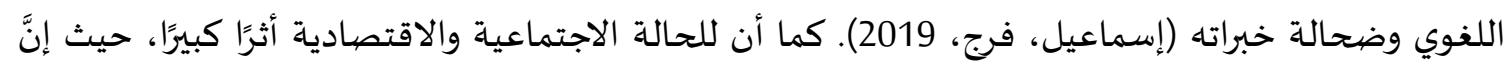

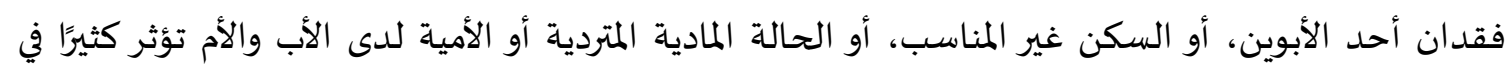

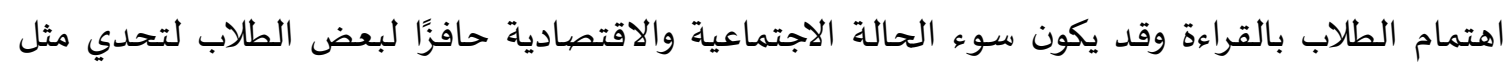
هذه الظرف والتغلب عليها (عاشـور، الحوامدة، 2007). - أسباب تعود إلى الكتاب المدرسي: كبعض موضوعات الكتب غير شائقة، ولا مثيرة لرغبة الطلاب، ولا تلبي

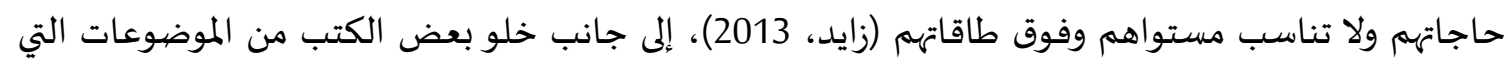

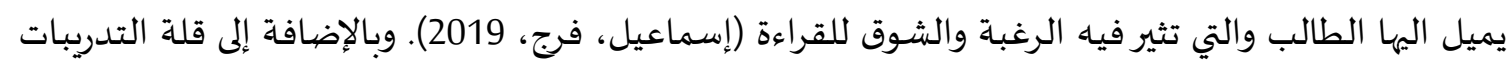

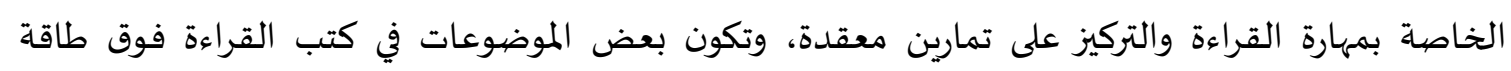
الطالب، حيث أنها لا تتناسب مع قدراته العقلية (عاشور، الحوامدة، 2007)، وتسلسل والفيل المهارات القرائية

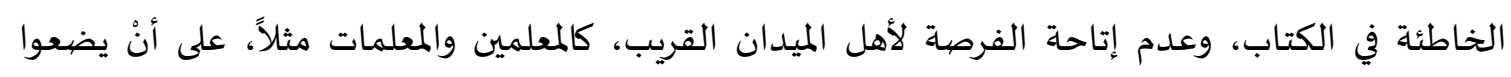


بصمتهم القريبة من المتعلمين في الكتاب، لذلك نرى هذه الفجوة ما بين الكتاب والمتعلمين، وقلة إجراء

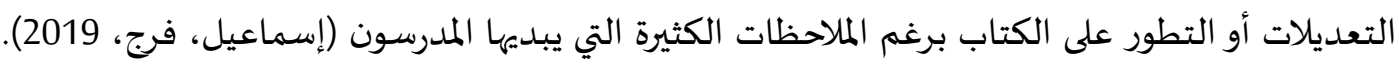

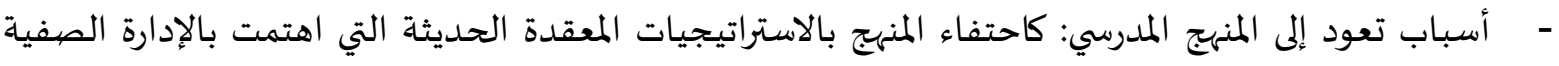

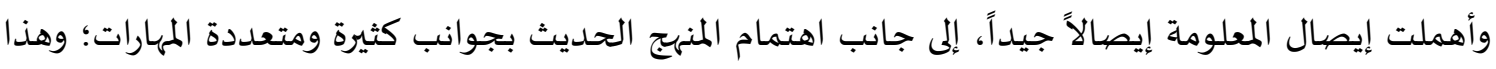

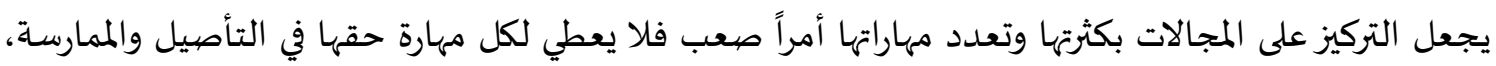

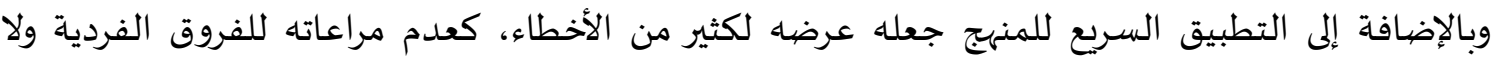

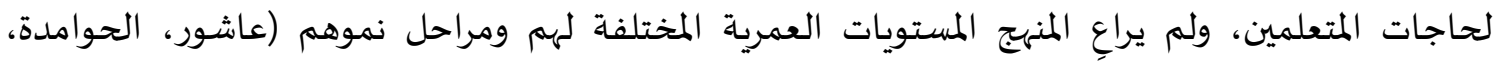

- أسباب تعود إلى المؤسسة التعليمية الكبرى: كقلة الفعاليات الخاصة بالقراءة ونشرها على المدارس والمحافل

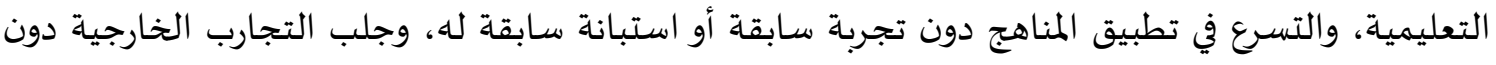

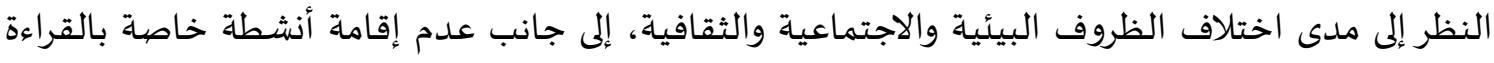

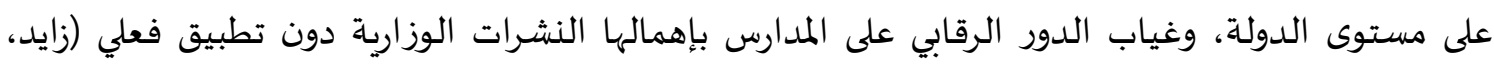

سادساً: سبل معالجة الضعف القرائي

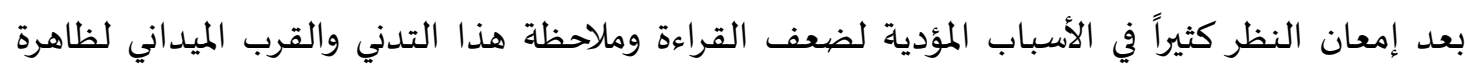

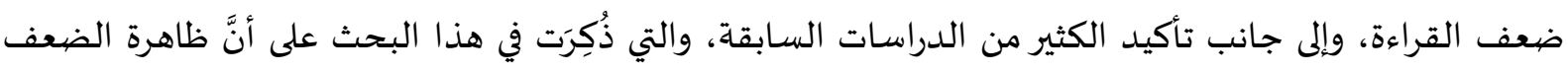

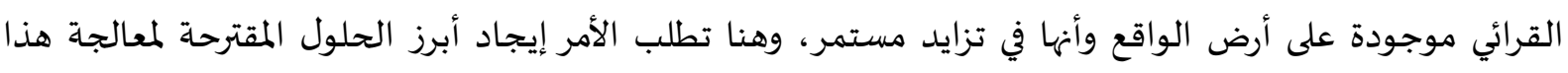
الضعف ومن تلك الحلول من وجهة نظر الباحث القريب من ميدان التعليم: - حلول خاصة بالأسرة: قد يغيب عن أذهان الكثير عنصر مهم جدًا وخفي في العملية التعليمية ومؤثر وهو

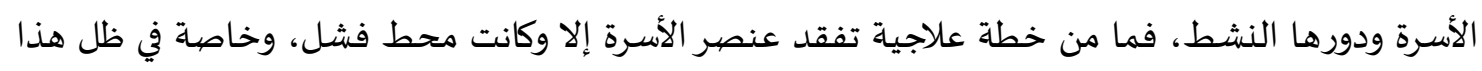

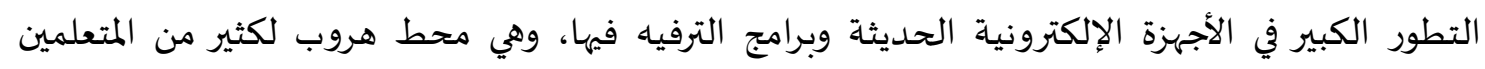

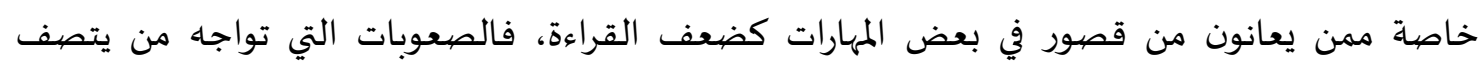

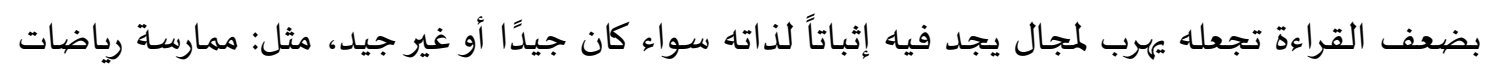

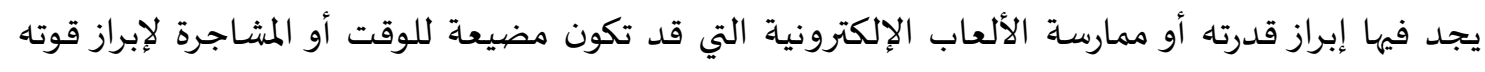

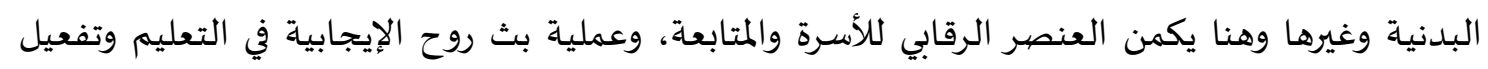
دورهم في التحفيز والإثابة والعقاب.

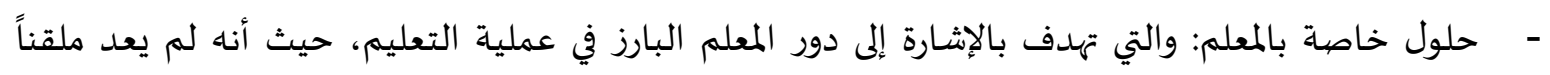

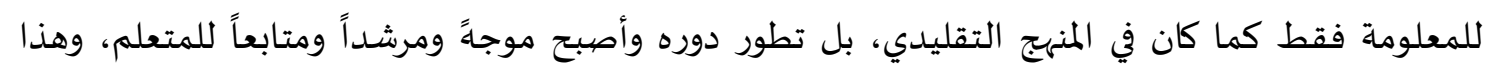

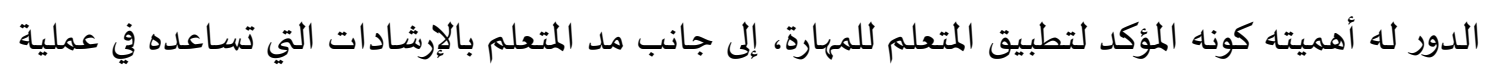

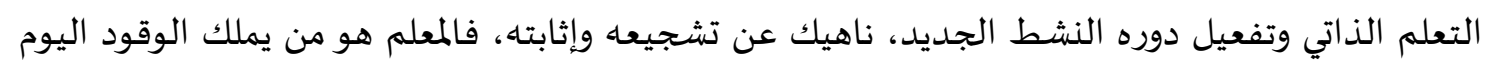

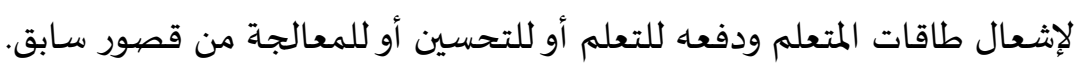

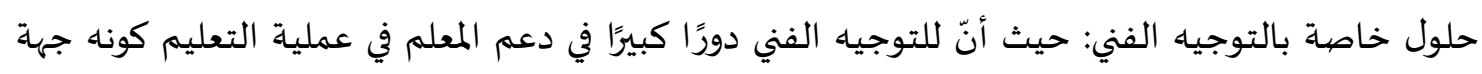

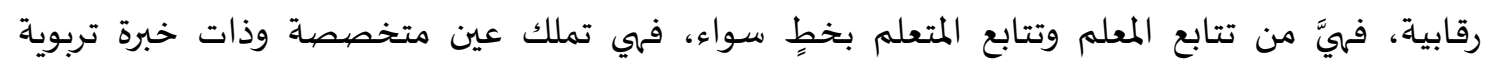

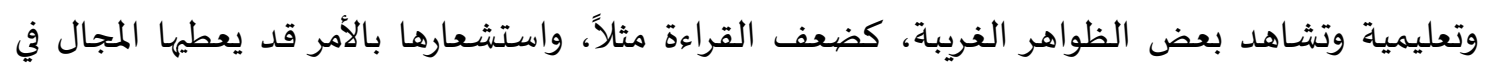


التدخل المبكر، وتوجياء المعنيين بالأمر نحو خطط علاجية مهمة وتهيئة الجو المناسب للمعلم والمتعلم لتدارك

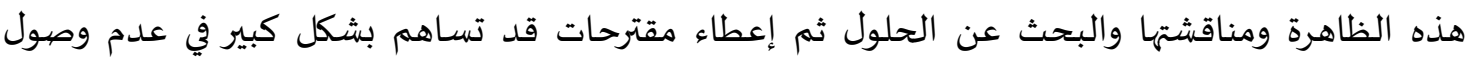
الظاهرة لمشكلة حقيقية مخيفة ومهددة للأجيال، إلى جانب دورها المهم في تفعيل الأنشطة التعليمية

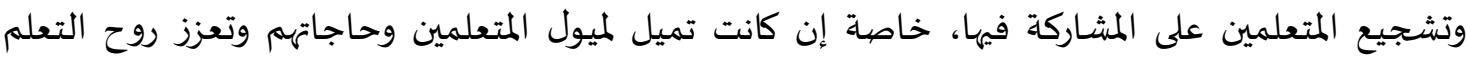

- حلول خاصة بالمنهج: أي لابد أن يراعي المنهج ميول المتعلمين وحاجاتهم والفروق الفردية بينهم، بل ويشركهم

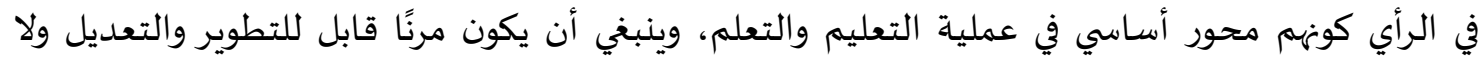

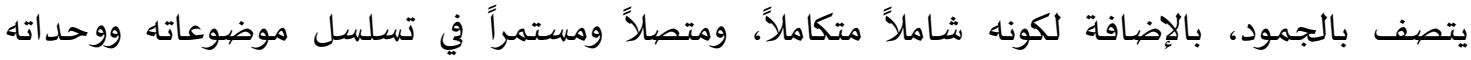

- حلول خاصة بالمؤسسة التعليمية الكبرى: عند ذكر المؤسسة المخولة بعملية التربية والتعليم فلابد الإشارة

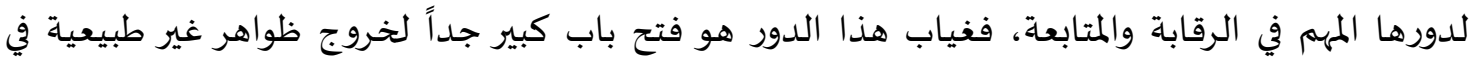

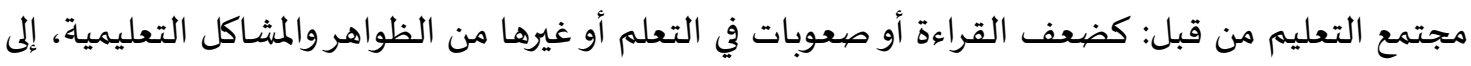
جانب تفعيل دورها التوعوي، وتفعيل دورها الميداني بتقديم كافة السبل والخدمات لجهاتها التعليمية

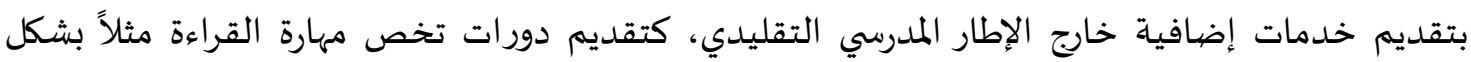
فصلي لمعالجة القصور الذي قد يحدث في التعليم المدرسي. مما سبق يتبين للباحث ضرورة تكامل الأدوار ما بين الأسرة والمعلم، والتوجيه الفني والمنهج المدرسي، والمدرسة والمؤسسة التعليمية الكبرى لمعالجة ضعف القراءة عند الطلاب، إذ يجب توطيد ذلك الرابط، في إطار متابعة الطلاب في تحصيلهم وتقدمهم وما يواجهون من مشكلات تعليمية، إضافة إلى ضرورة قيام المدرسة بدورها

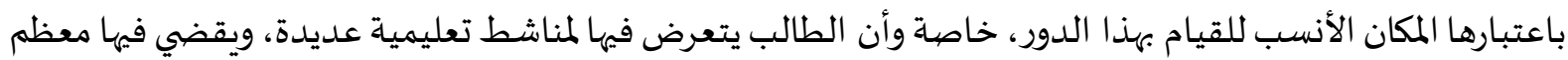
أوقات يقظته، فضلاً عن دور المناهج المدرسية التي ينبغي تصميمها بأسلوب يدعو إلى إطلاق أفكار الطلاب، وإثارة

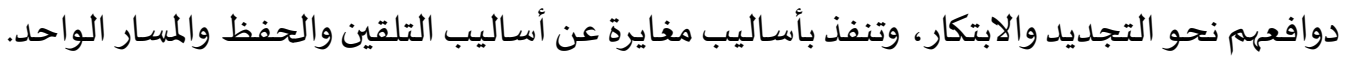

ثانياً- الدراسات السابقة: تم في هذا القسم تناول الدراسـات السابقة المتعلقة بموضوع البحث، العبية منها والأجنبية، وتم ترتيبها زمنياً من الأقدم إلى الأحدث، كما يأتي:

دراسة ماكاندلز وزملاءه (McCandliss, Bruce, Beck, Isabel L., Sandak, Rebecca, \& Perfetti, 2013)، التي هدفت إلى التعرف على مهارات القراءة للأطفال الذين يعانون من نقص في مهارات بناء الكلمات، في السنوات التالية للصف الأول، وتم تتبع تقدم الطلاب عبر (20) جلساتة في البداية، وبينت النتائج أوجها القصور في مهارات بناء الكلمات لدى الطلاب، وفهم القراءة، وههارات الوعي الصوتي. وأن الطلاب لم يشاركوا في فك التشفير الأبجدي الكامل. - دراسة بوخريصة وزعطوط (2014): والتي هدفت إلى التعرف على أسباب تدني القراءة في المدارس الابتدائية

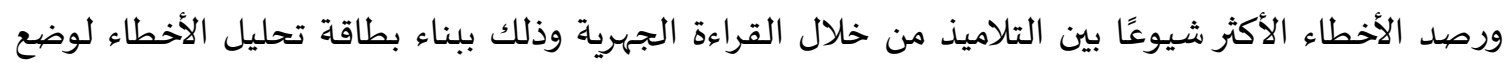

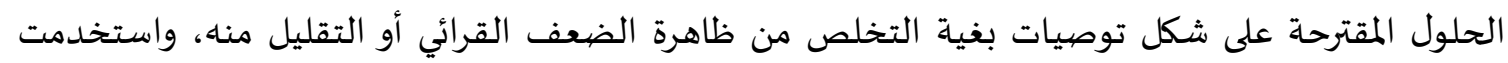

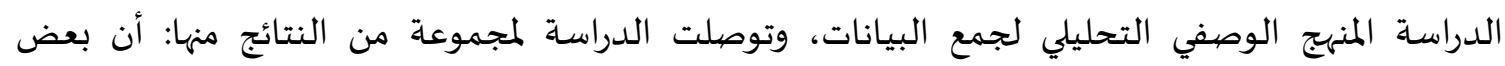
التلاميذ يخطئون في قراءة ألفاظ كثيرة من حيث الحذف والزيادة، بالإضافة عدم قراءة الكلمات بالشكل ولئل 
الصحيح ولاسيما أواخرها ويعود ذلك لأسباب كثيرة أهمها كثرة الأعداد في الفصل الواحد، وضعف البصر، وكثرة غياب التلاميذ عن المدرسة. دراسة الهاشمي والبوسعيدي والموسوي وكاظم والخائفي (2016): والتي هدفت إلى تحديد مظاهر الضعف

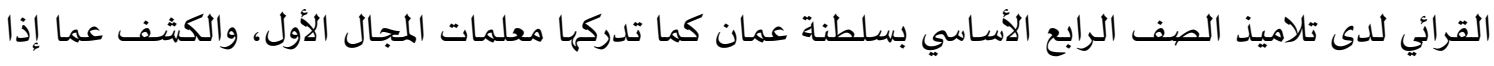

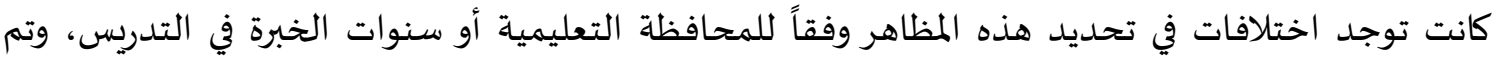

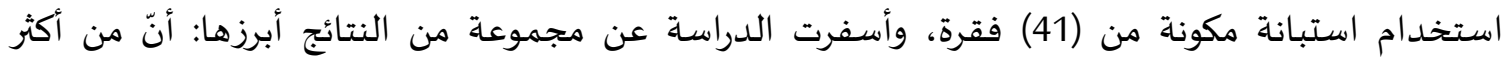

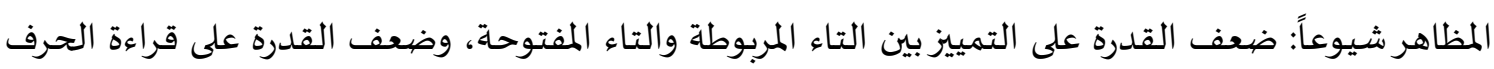
المشدد، وقراءة الجملة كلمة بكلمة، والبطء في في القراءة.

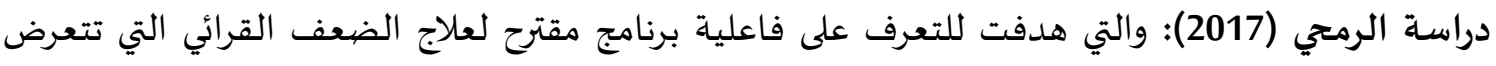

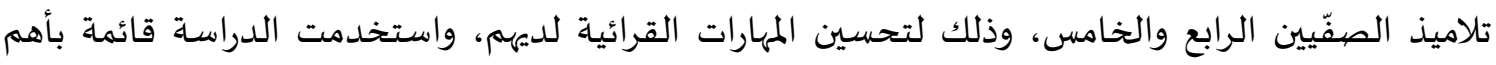

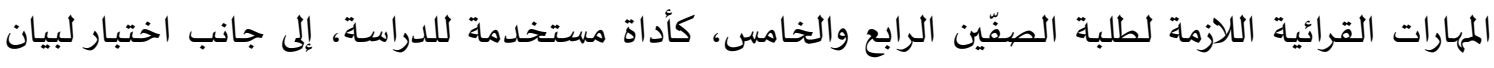

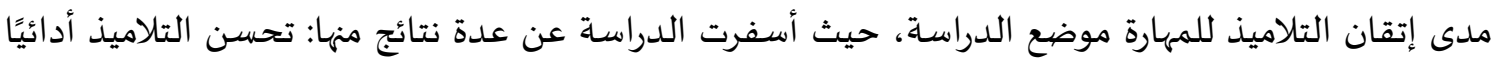

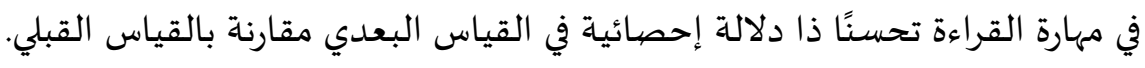

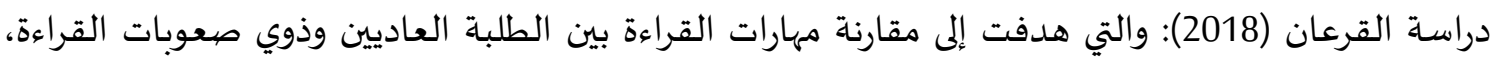

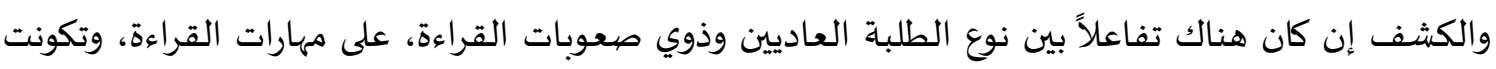

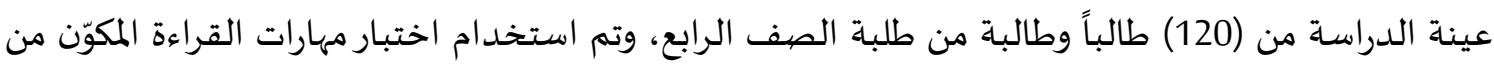

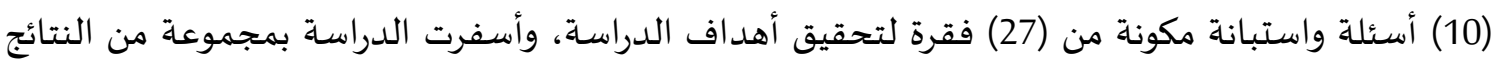

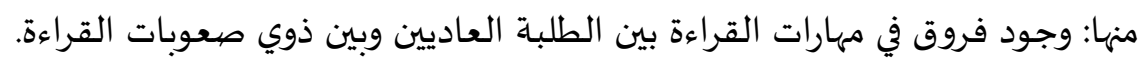

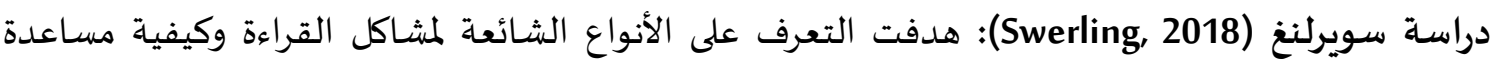

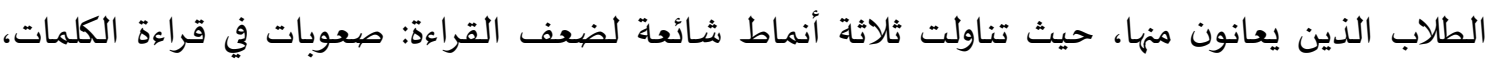

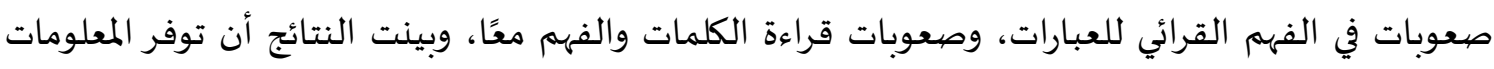

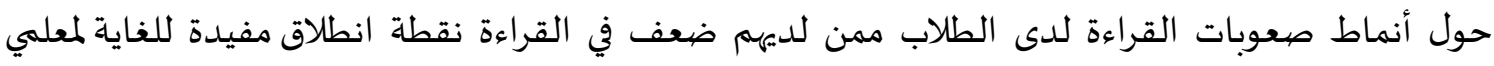

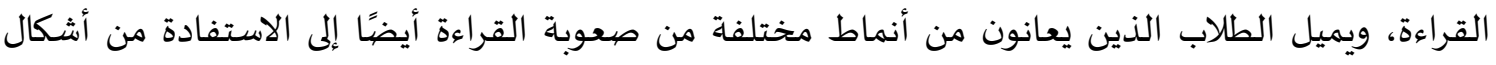

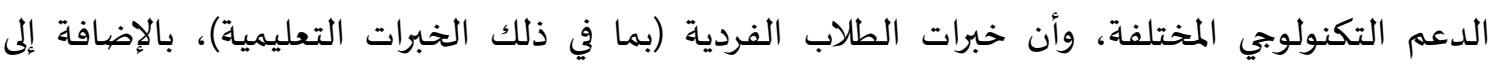

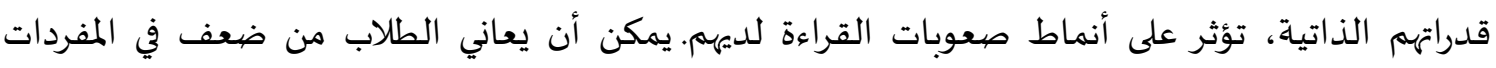

$$
\text { بسبب الإعاقات اللغوية. }
$$

دراسة إسماعيل، فرج (2019): هدفت إلى التعرف على أسباب تدني القراءة والكتابة في المرحلة المتوسطة من

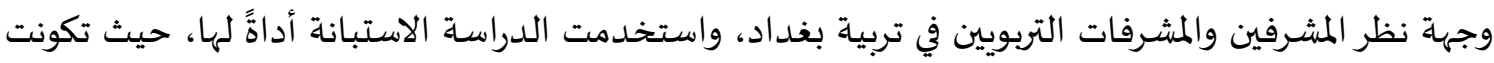

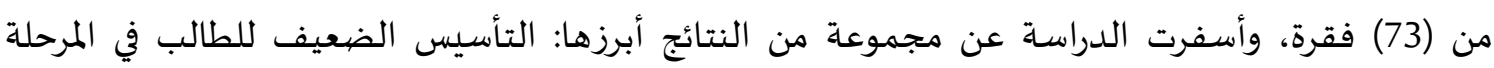

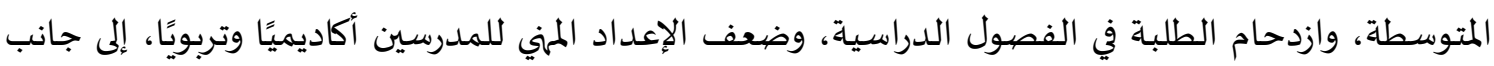
ندرة المكتبات المدرسية وعدم الاهتمام بالقراءة الحرة. دراسة أحمد (2019): هدفت للتعرف على أثر استخدام الاستراتيجية التذكّرية لتعلم اللغة العربية في تحسين

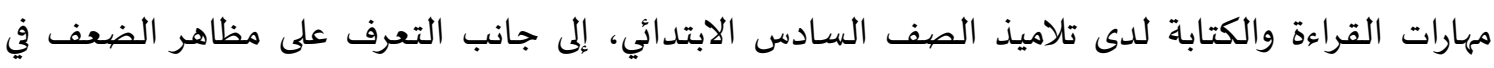

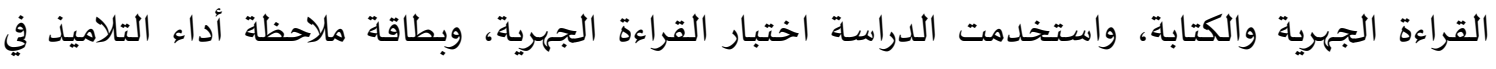

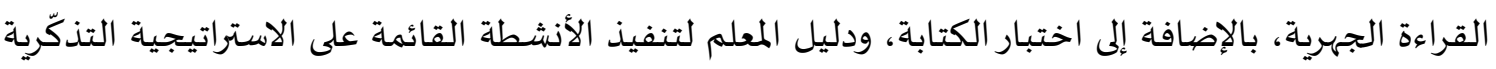


لتعلم اللغة، وتم تطبيقها على عينة بحث مكونة من (20) تلميذًا وتلميذة، وأسفرت بنتائج مهمة منها: وجود

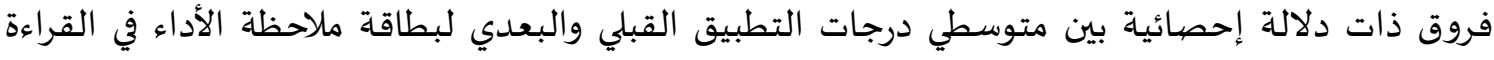

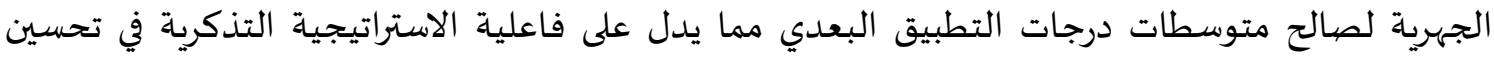
الضعف في مهارة القراءة الجهرية لدى التلاميذ. - دراسة اليونسكو (UNESCO, 2019) هدفت إلى التعرف على طرق تحسين معرفة القراءة والكتابة، وتم

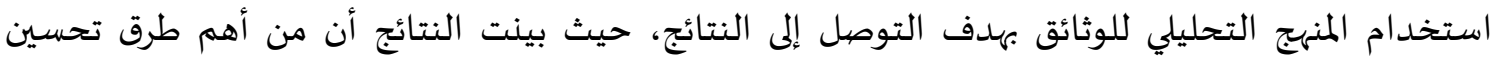

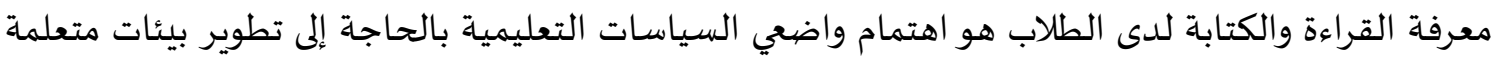

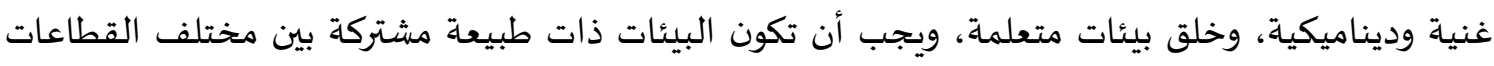

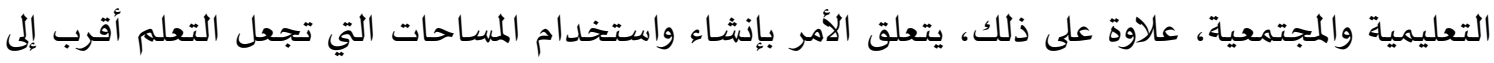
الحياة اليومية للطلاب وهي الفكرة المركزية للتعلم مدى الحئه الحياة.

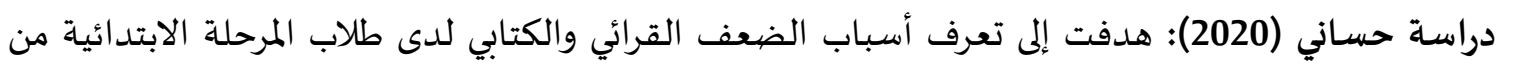

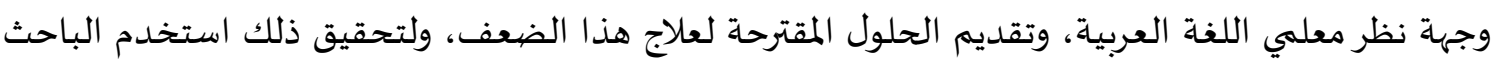

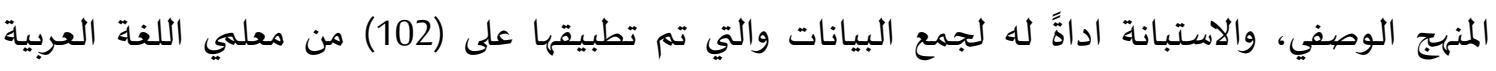

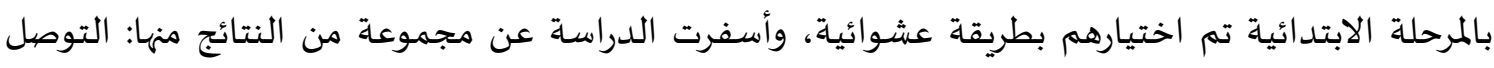

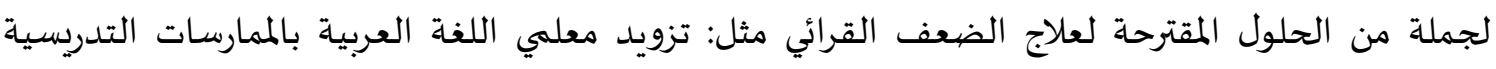

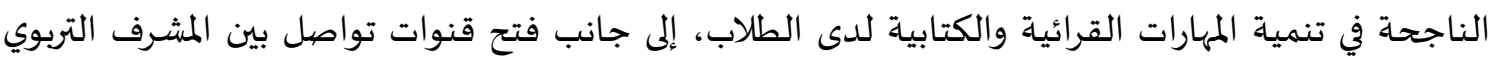

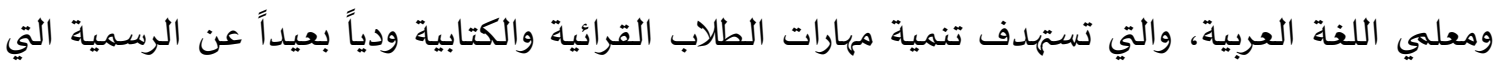
تطغى على الزيارات المجدولة.

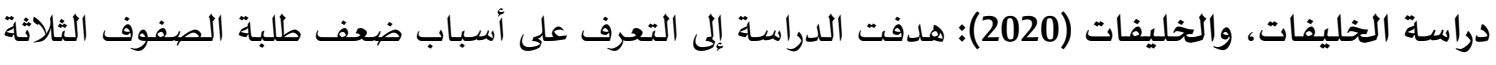

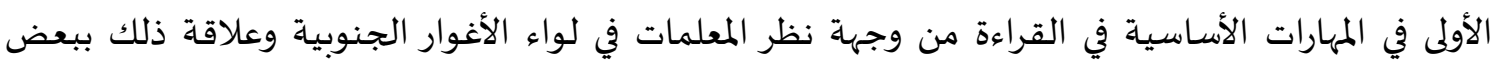

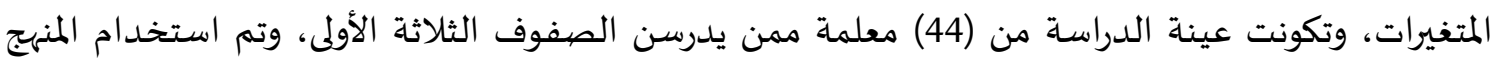

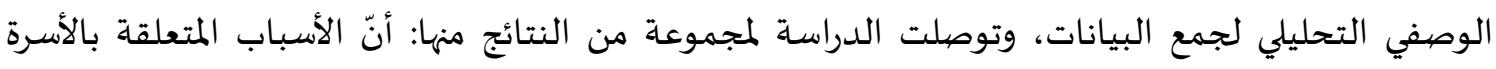
جاءت بالمرتبة الأولى ثم المتعلقة بالبيئة التعليمية ثم بالطالب وأخيرًا بالمعلم.

تعقيب على الدراسـات السابقة

من خلال استعراض الدراسات السابقة يتبين ما يلي:

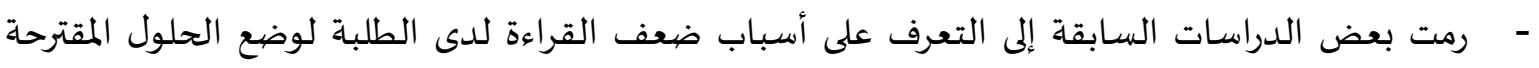

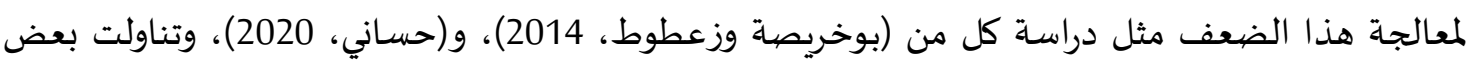

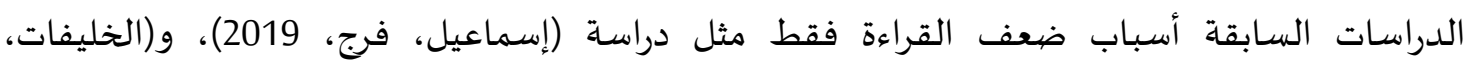
والخليفات، 2020)، وسويرلنغ (Swerling, 2018). - ارتكزت بعض الدراسات السابقة على فاعلية برنامج مقترح لعلاج الضعف القرائي مثل دراسة (الرمجي، 2017 - اتجهت دراسة (أحمد،2019) نحو التعرف على أثر استخدام الاستراتيجية التذكّرية لتعلم اللغة العربية في تحسين مهارات القراءة والكتابة. 
- استخدمت بعض الدراسات السابقة المنهج الوصفي التحليلي مثل دراسة (إسماعيل، فرج، 2019)،

$$
\text { و(حساني، 2020)، و(الخليفات، والخليفات، 2020). }
$$

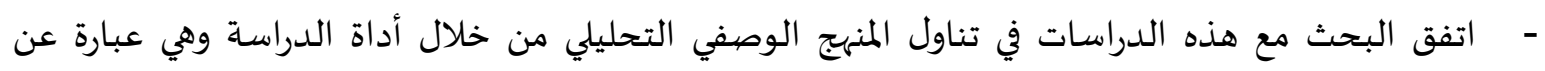

$$
\text { استبانة وزعت على المعلمين والمعلمات. }
$$

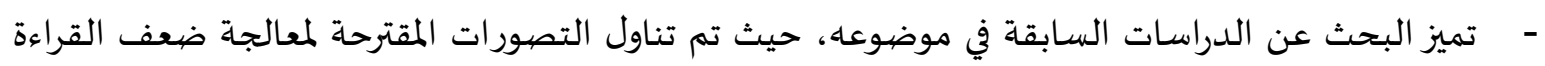

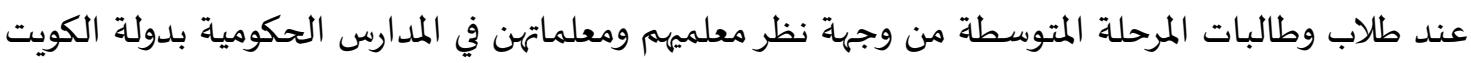

$$
\text { والمتعلقة بمجالات متعددة ومختلفة. }
$$

- وفي ضوء عرض الدِّراسات السابقة استفاد الباحث من تلك الجهود في تصميم أداة البحث، وفي مناقشة

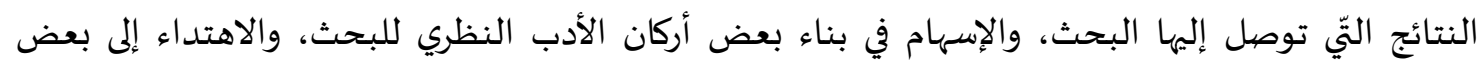

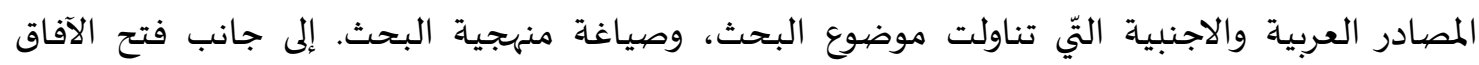
بتوصيات بعض الدراسات السابقة لتناول محور البحث الحالي.

3. منهجية البحث وإجراءاته.

منهج البحث:

استخدم الباحث المنهج الوصفي التحليلي، وهو المنهج الذي يقوم على تحديد ووصف الحقائق المتعلقة

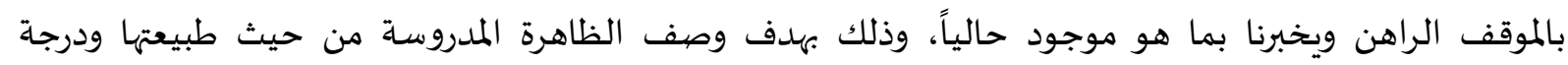

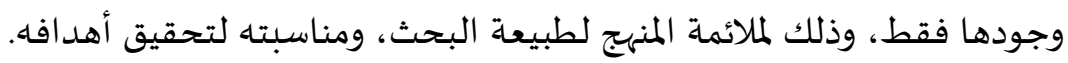

تكوّن مجتمع البحث من مُعلِّمي ومُعِلّمات المرحلة المتوسطة في منطقة مبارك الكبير التّعليمية في دولة

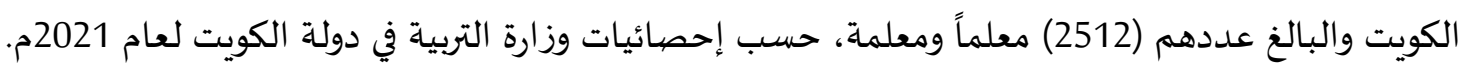

عينة البحث: تكونت عينة الدراسة من (350) مُعِلِماً ومُعلِّمة تم اختيارهم بشكل عينة عشوائية طبقية مراعية لتوزيع

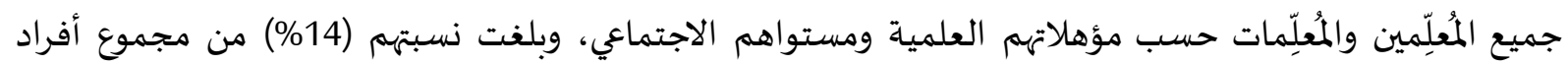

\begin{tabular}{|c|c|c|}
\hline النسبة المئوية & التكرار & متغير الجنس \\
\hline 52.3 & 183 & ذكر \\
\hline 47.7 & 167 & أنثى \\
\hline 100.0 & 350 & المجموع \\
\hline
\end{tabular}

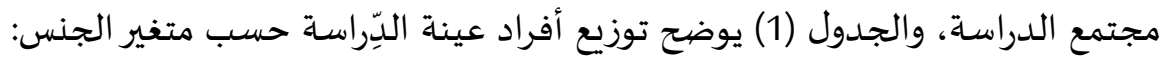

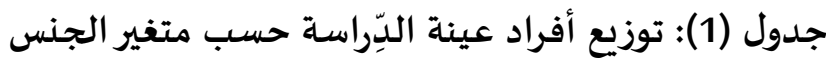

أداة البحث:

تم إنشاء وتطوير الاستبانة بالاعتماد على الدراسات السابقة، وتم الاعتماد على دراسة كل بوخريصة وزعطوط (2014)؛ والرمحي (2017)؛ وحساني (2020) لتطوير أداة الدراسة المتعلقة بالتصورات المقترحة لمعالجة 
ضعف القراءة عند طلاب وطالبات المرحلة المتوسطة من وجهة نظر معلميهم ومعلماتهن في المدارس الحكومية بدولة

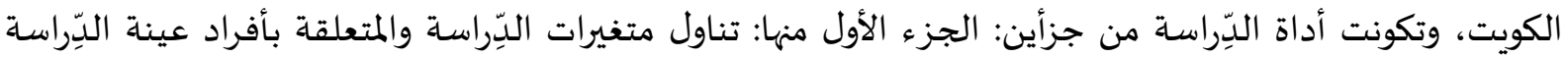

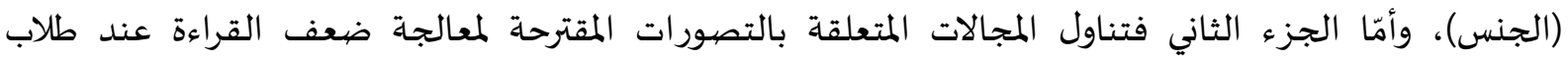
وطالبات المرحلة المتوسطة من وجهة نظر معلميهم ومعلماتهن في المدارس الحكومية بدولة الكويت وهي (تصورات

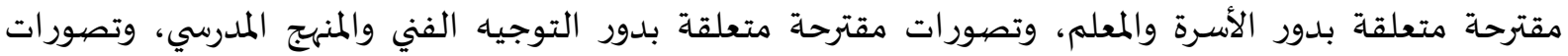
مقترحة متعلقة بدور المدرسة والمؤسسة التعليمية الكبرى). وتم استخدام مقياس ليكرت الخماسي. والمتمثل في الآتي:

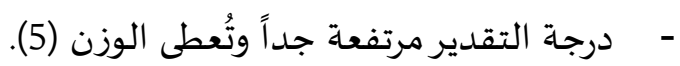

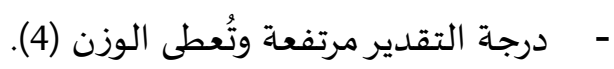

-

-

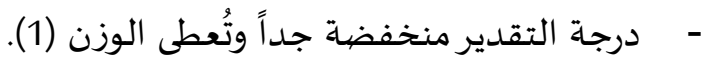

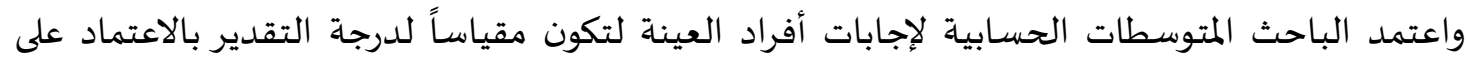
المعيار التالي في الحكم على تقدير المتوسطات الحسابية، وذلك بتقسيم درجات التقدير إلى ثلاثة مستويات (كبيرة، متوسطة، منخفض) بالاعتماد على المعادلة التالية وهي معيار التصحيح.

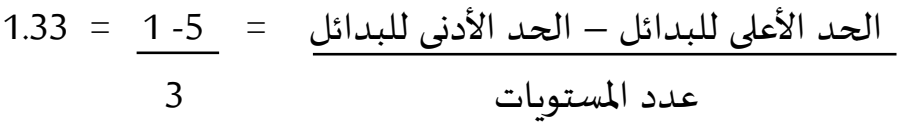

$$
\begin{aligned}
& \text { المدى الأول: (1- 2.33) درجة تقدير منخفضية. } \\
& \text { المدى الثاني: (2.34- 3.67) درجة تقدير متوسطة. } \\
& \text { المدىى الثالث: (3.68 - 5) درجة تقدير كبيرة. }
\end{aligned}
$$

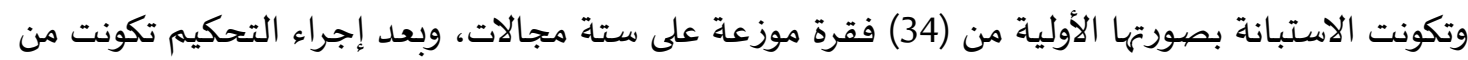

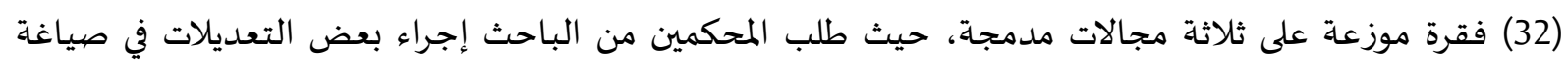
العبارات، وحذف بعضها، وتقسيم إحدى العبارات إلى فقرتين كونها فقرة مركبة.

صلدق أداة البحث:

للتحقق من صددق أداة البحث تم عرضها على (7) من المحكمين من ذوي الاختصاص والخبرة من أعضاء

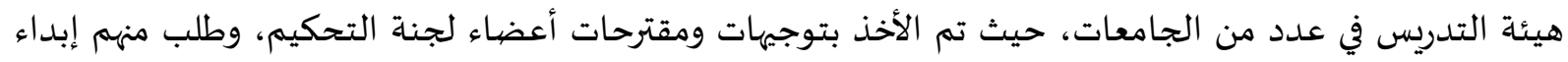

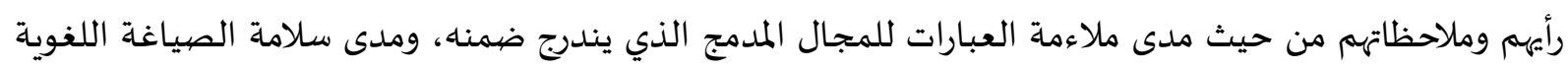

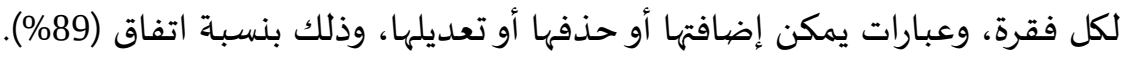

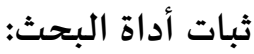

للتحقق من ثبات الأداة، قام الباحث بحساب معاملات الثبات لهذه الاستبانة بتطبيقها على عينة مكونة من

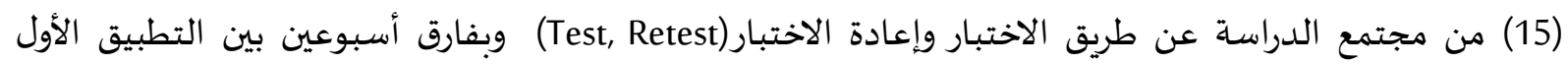

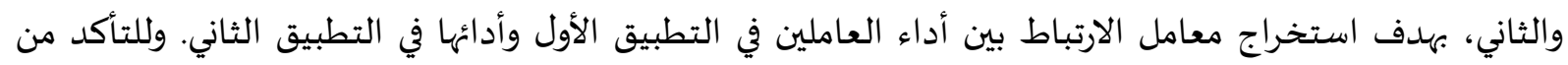

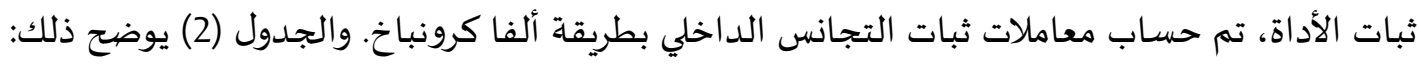


جدول (2): معامل ثبات الإعادة معامل ارتباط بيرسون والاتساق الداخلي ألفا كرونباخ للمجالات والأداة ككل

\begin{tabular}{|c|c|c|c|}
\hline كرونباخ الاتساق ألفا & ثبات الإعادة & العبارات & المجال \\
\hline 0.84 & 0.83 & 11 & تصيورات مقترحة متعلقة بدور الأسرة والمعلم \\
\hline 0.87 & 0.87 & 11 & تصورات مقترحة متعلقة بدور التوجيه الفني والمنهج المدرسي \\
\hline 0.84 & 0.88 & 10 & تصورات مقترحة متعلقة بدور المدرسة والمؤسسـة التعليمية الكبرى \\
\hline 0.85 & 0.86 & 32 & 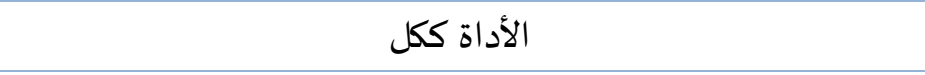 \\
\hline
\end{tabular}

المعالجة الإحصائية

للإجابة عن أسئلة البحث استخدم الباحث برنامج التحليل الاحصائي (SPSS)، حيث تم استخدام اختبارات

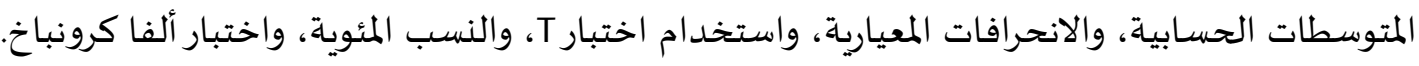

4. عرض نتائج البحث ومناقشتها.

النتائج المتعلقة بالسؤال الأول: ما التصهورات المقترحة لمعالجة ضعف القراءة عند طلاب وطالبات المرحلة

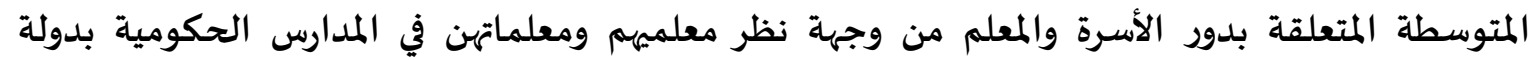

الكويت؟

للإجابة عن هذا السؤال تم استخراج المتوسطات الحسابية والانحرافات المعيارية لتقديرات المعلمين

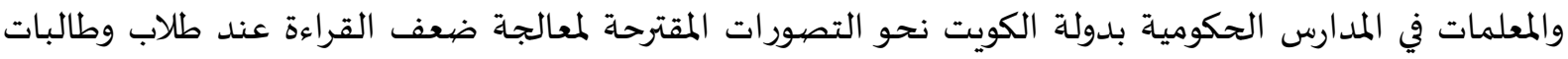

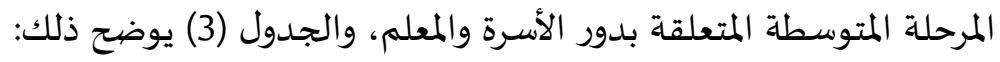

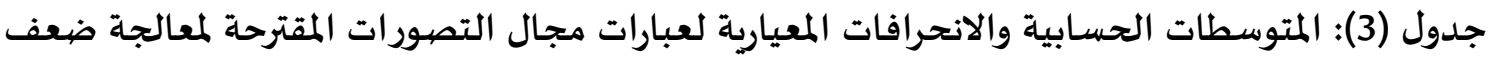
القراءة عند طلاب وطالبات المرحلة المتوسطة المتعلقة بدور الأسرة والمعلم مرتبة تنازلياً

\begin{tabular}{|c|c|c|c|c|c|}
\hline درجة التقدير & 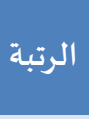 & الالمحراف & 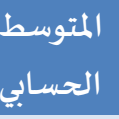 & العبارات & $\hat{\imath}$ \\
\hline كبيرة & 1 & 0.74 & 4.33 & توفير مخزون علمي وثقافي لدى المعلم يؤهله لمعالجـة الضعف القرائي عند & 9 \\
\hline كبيرة & 2 & 0.67 & 4.32 & مراعاة الأسرة لمشكلات الطالب المختلفة والوقوف معه ليتجاوزها & 4 \\
\hline كبيرة & 3 & 1.04 & 4.06 & استمرار المعلم بتحسين وتطوير مهارات القراءة لدى الطلاب & 8 \\
\hline كبيرة & 4 & 0.81 & 3.99 & تشجيع الأسرة للطالب حتى يتم تطوير مهاراته القرائية المختلفة & 3 \\
\hline 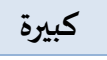 & 5 & 0.67 & 3.92 & حرص الأسرة على متابعة تقييم المعلم وتقويمه للطالب & 5 \\
\hline كبيرة & 6 & 1.01 & 3.79 & اهتمام المعلم بتشخيص الطلاب ومهاراتهم القرائية & 6 \\
\hline كبيرة & 7 & 0.78 & 3.77 & متابعة المعلم مدى تقدم الطلاب وتحسنهم في الخطط العلاجية المنفذة & 11 \\
\hline كبيرة & 8 & 0.83 & 3.76 & توفّير الأسرة لكافة السبل الخاصية بالطالب لتحسيّين مهاراته القرائية & 1 \\
\hline كبيرة & 9 & 1.10 & 3.71 & تنويع المعلم بطرائق التدريس وأساليبه الخاصهة بالمهارات القرائية & 7 \\
\hline 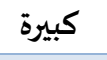 & 9 & 0.64 & 3.71 & امتلاك المعلم شخصية مرنة ومحببة للتعليم & 10 \\
\hline 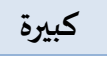 & 11 & 1.16 & 3.69 & اهتمام الأسرة بتعلّيم الطالب لمهارات القراءة الصحيحةة & 2 \\
\hline 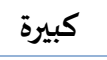 & & 0.54 & 3.91 & المتوسط الكلي للتصهورات المقترحة المتعلقة بدور الأسرة والمعلم & \\
\hline
\end{tabular}


يبين الجدول (3) المتوسطات الحسابية والانحرافات المعيارية لعبارات مجال التصورات المقترحة لمعالجة

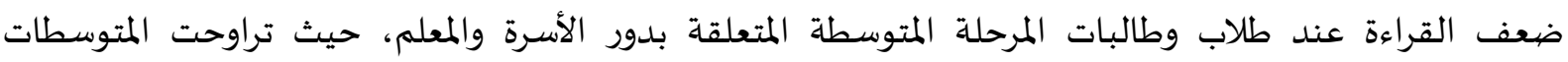
الحسابية ما بين (3.69- 4.33) ضمن درجة تقدير كبيرة، حيث جاءت العبارة رقم (9) والتي تنص على " توفير مخزون

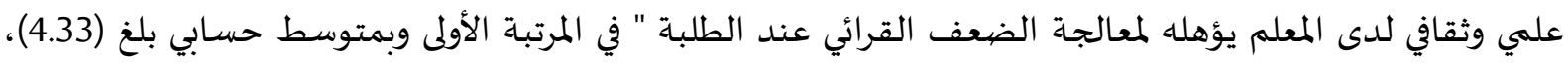

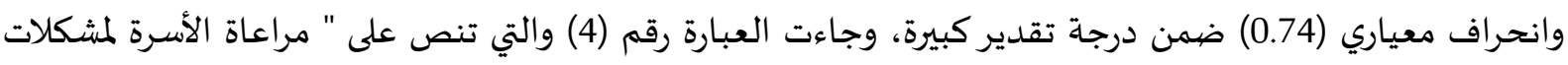

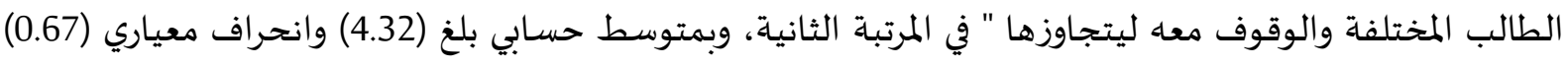

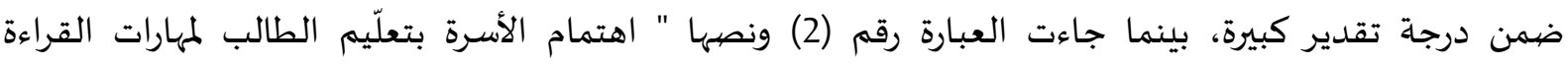

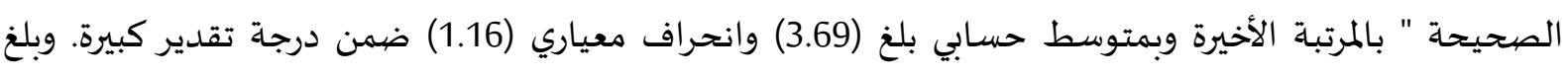

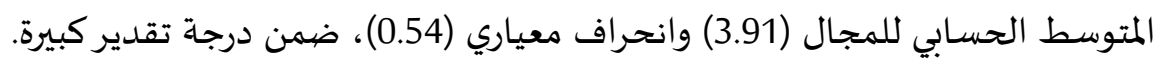

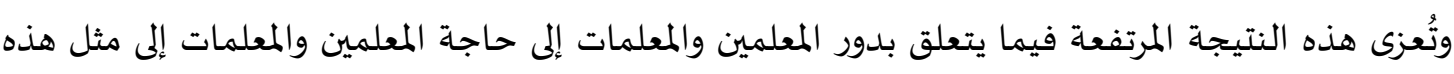

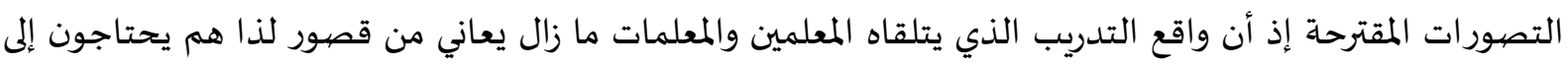

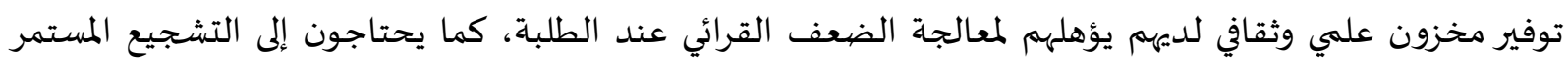

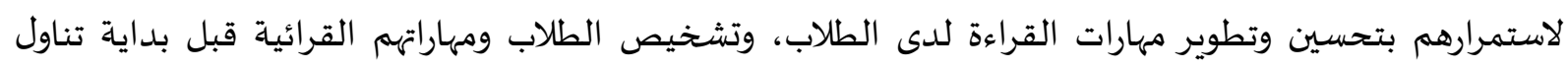

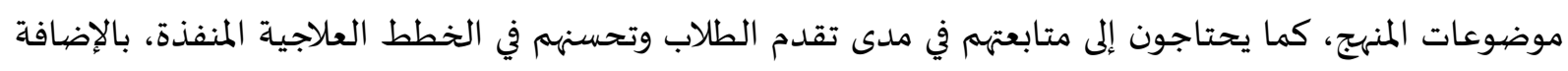

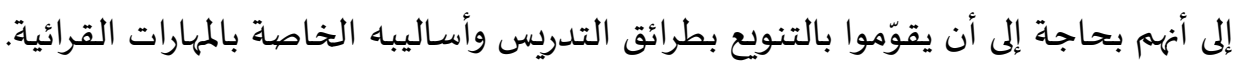

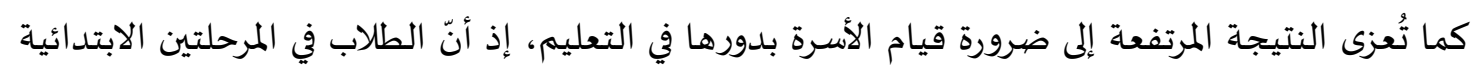

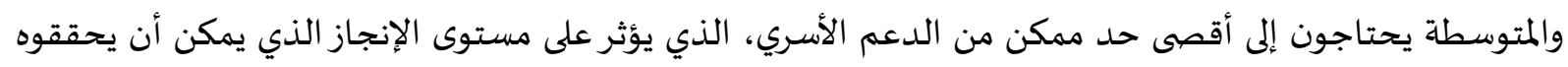

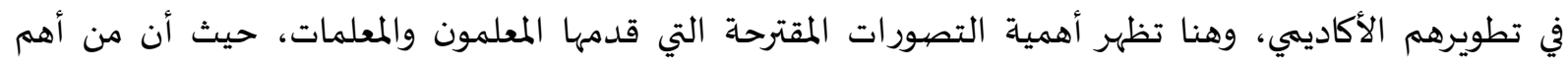

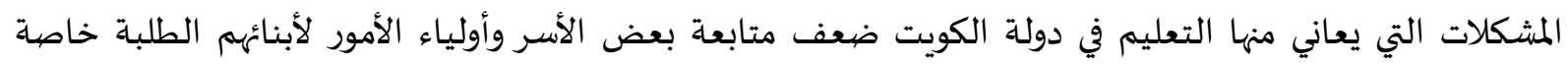

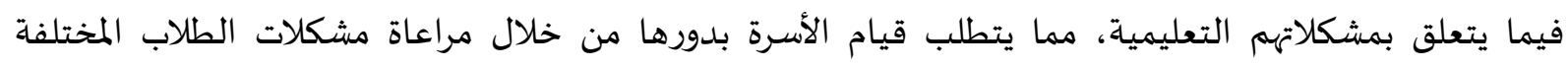
والوقوف معهم لتجاوزها، وتشجيع أبنائهم الطلاب ليتم تطوير مهاراتهم القرائية المختلفة، كما يتطلب الأمر قيام الأسرة بالتنسيق مع المدرسة والمعلمين والمعلمات لمتابعة تقييم أبنائهم.

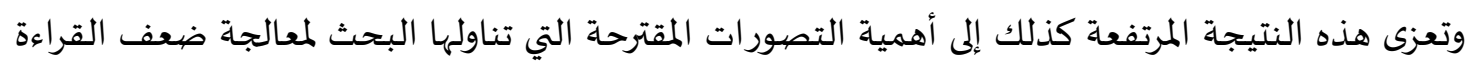

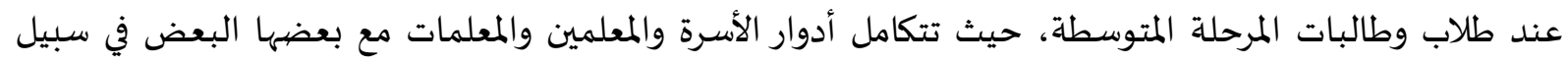
تقديم حلول مشتركة لضعف القراءة عند الطلاب والطالبات في المرحلة المتوسطة.

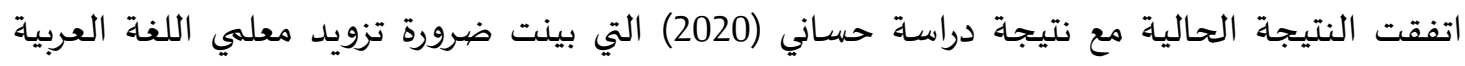

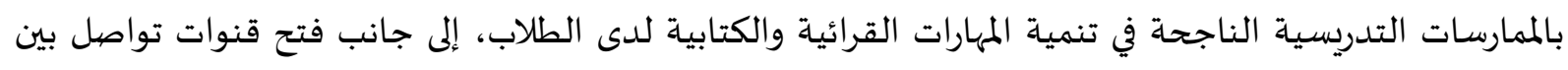

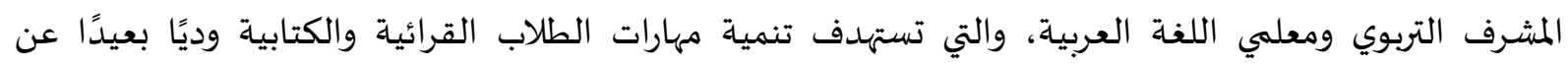
الرسمية التي تطغى على الزيارات المجدولة. 
النتائج المتعلقة بالسؤال الثاني: ما التصورات المقترحة لمعالجة ضعف القراءة عند طلاب وطالبات المرحلة

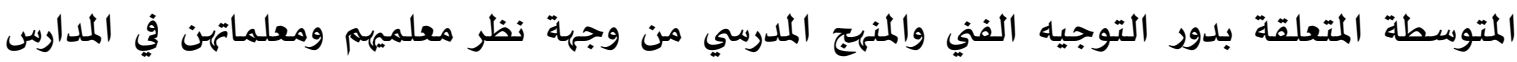

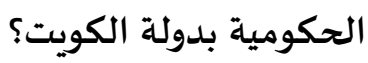
للإجابة عن هذا السؤال تم استخراج المتوسطات الحسابية والانحرافات المعيارية لتقديرات المعلمين

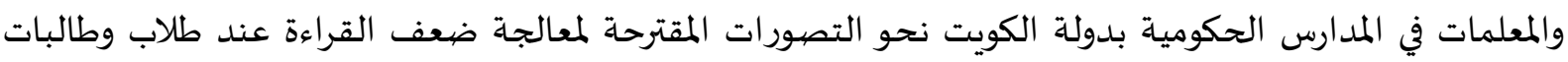

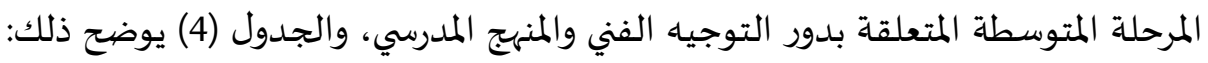

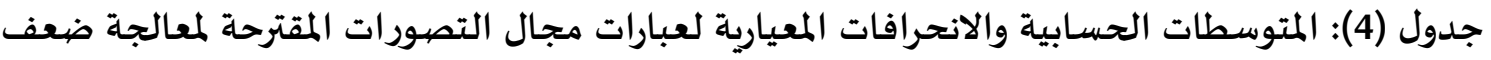

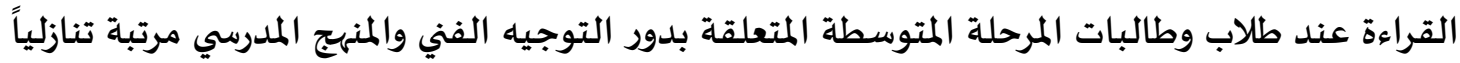

\begin{tabular}{|c|c|c|c|c|c|}
\hline التقدير & الرتبة & 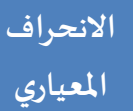 & المستوسط & 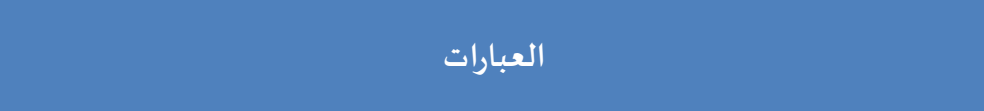 & $\hat{r}$ \\
\hline كبيرة & 1 & 0.67 & 4.48 & مراقبة التوجيه الفني لمدى التزام المعلمين بالخطط العلاجية المقدمة للطلاب & 2 \\
\hline كبيرة & 2 & 0.81 & 4.23 & حرص التوجيه الفني بمد المعلمين بكافة التصهورات الخاصة بمعالجة الضعف & 3 \\
\hline كبيرة & 3 & 0.61 & 4.16 & توفير أنشطة تعليم متنوعة تناسب المراحل التعليمية المختلفة في المنهجج المدرسي & 10 \\
\hline كبيرة & 4 & 0.78 & 4.12 & تحفيز التوجيه الفني لكل البوادر الخاصة بمعالجة مشكلات الطلاب & 4 \\
\hline كبيرة & 5 & 0.50 & 4.07 & حرص التوجيه الفني على إنجاز الخطط العلاجية بأقل وقت وبأفضل نتيجة & 6 \\
\hline كبيرة & 6 & 0.70 & 3.91 & تشجيع استخدام الوسائل التعليمية والتكنولوجية الحديثة عند تنفيذ الدروس & 9 \\
\hline كبيرة & 7 & 0.50 & 3.89 & توفير نصوص شيقة وجاذبة للتعلم في المنهج المدرسي & 7 \\
\hline كبيرة & 8 & 0.81 & 3.84 & تشجيع التوجيه الفني المعلمين على التنويع في طرق التدريس وأساليبه & 5 \\
\hline كبيرة & 9 & 0.63 & 3.38 & تنويع الأنشطة الخاصة بمهارات القراءة في المنهج المدرسي & 8 \\
\hline كبيرة & 10 & 0.61 & 3.82 & تقديم التوجيه الفني دورات خاصة للمعلمين متعلقة بالضعف القرائي عند & 1 \\
\hline كبيرة & 11 & 0.81 & 3.78 & الاهتمام بالقراءة ومهاراتها المتنوعة في المنهجج المدرسي & 11 \\
\hline كبيرة & & 0.40 & 4.01 & المتوسط الكلي للتصورات المقترحة المتعلقة بدور التوجيه الفني والمنهجج المدرسي & \\
\hline
\end{tabular}

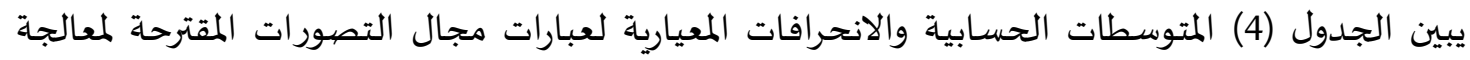

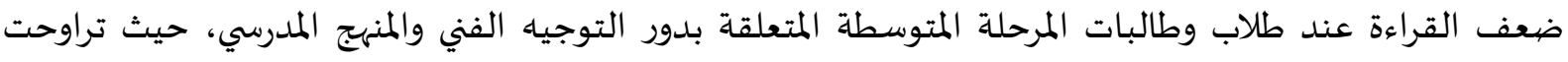
المتوسطات الحسابية ما بين (3.78 - 4.48) ضمن درجة تقدير كبيرة، حيث جاءت العبارة رقم (2) والتي تنص على "

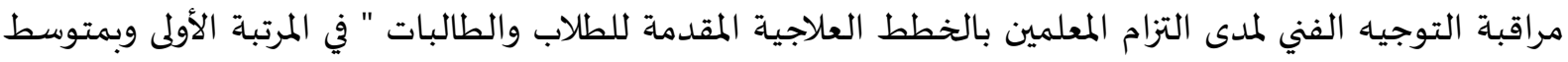

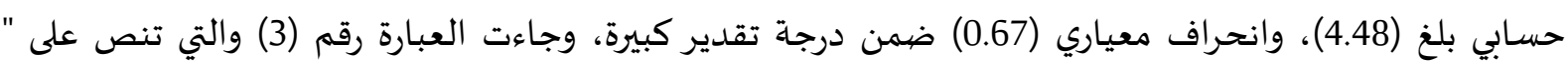

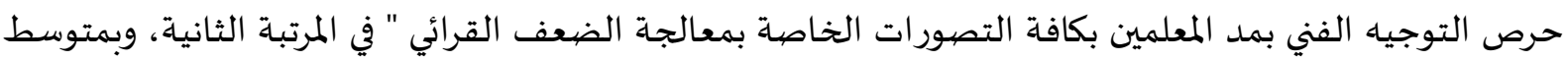
حسابي بلغ (4.21) وانحراف معياري (0.81) ضمن درجة تقدير كبيرة، بينما جاءت العبارة رقم (11) ونصهيا " الاهتمام

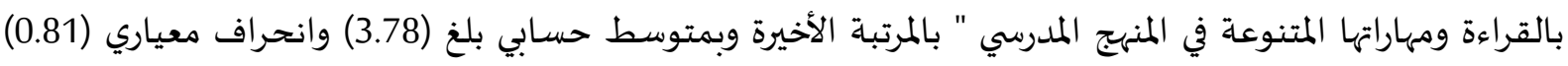

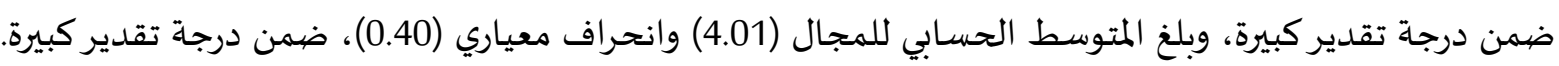
وتعزى هذه النتيجة إلى أن التوجياه الفني في دولة الكويت يعاني من قصهور في أداء دوره بالشكل المناسب،

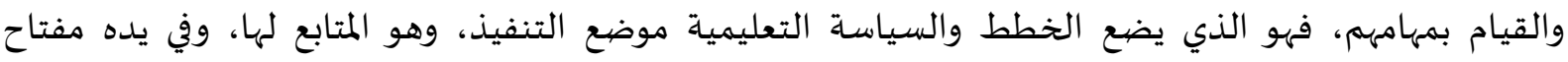

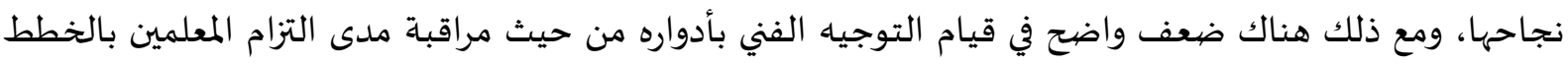


العلاجية المقدمة للطلاب، وتشجيع المعلمين والمعلمات على القيام بمبادرات خاصة لمعالجة مشكلات ضعف القراءة عند الطلاب، إضافة إلى متابعة المعلمين والمعلمات وتشجيعهيم على التنويع في طرائق التدريس وأساليبها.

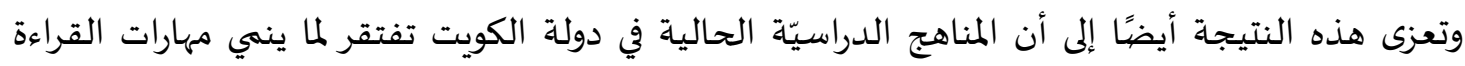

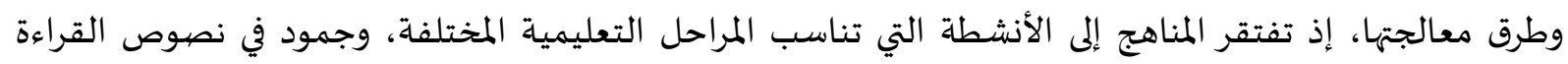

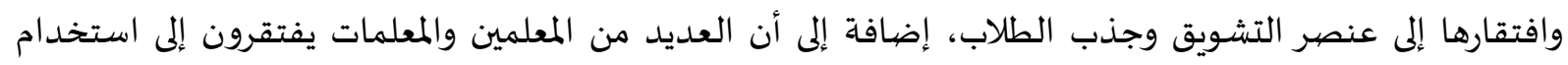

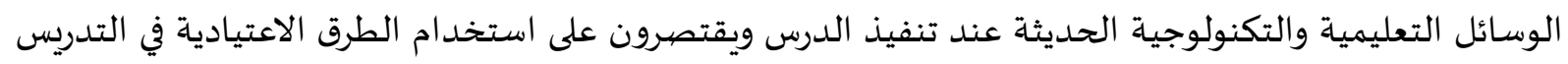
مما يضفي على المنهج طابع الجمود وعدم التشويق.

النتائج المتعلقة بالسؤال الثالث: ما التصهورات المقترحة لمعالجة ضعف القراءة عند طلاب وطالبات المرحلة

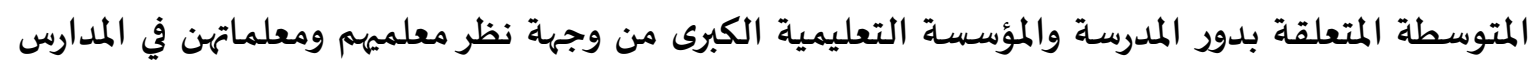

\section{الحكومية بدولة الكويت؟}

للإجابة عن هذا السؤال تم استخراج المتوسطات الحسابية والانحرافات المعيارية لتقديرات المعلمين

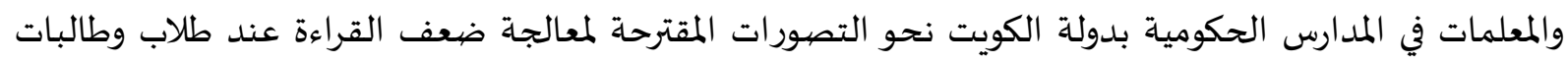

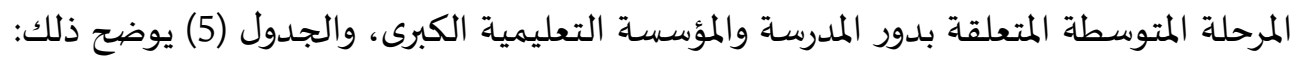

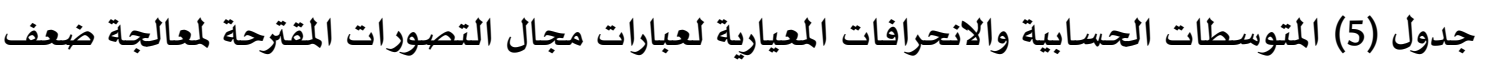
القراءة عند طلاب وطالبات المرحلة المتوسطة المتعلقة بدور المدرسة والمؤسسة التعليمية الكبرى مرتبة تنازلياً

\begin{tabular}{|c|c|c|c|c|c|}
\hline التقدير & 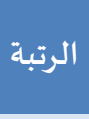 & 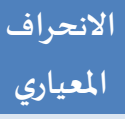 & الحستوسط الحسب & 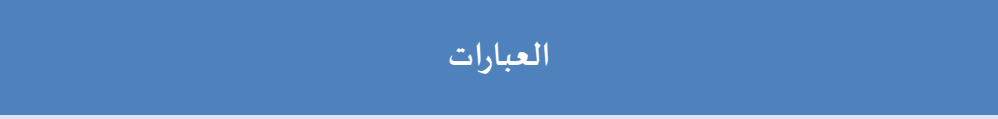 & $\hat{\imath}$ \\
\hline كبيرة & 1 & 1.00 & 4.11 & تقديم وسائل تعليمية وتكنولوجية حديثة في المدرسة & 1 \\
\hline كبيرة & 2 & 0.81 & 4.03 & توفير المؤسسة التعليمية الكبرى لكافة السبل لمعالجة مشكلات الطلاب وخاصهة & 8 \\
\hline كبيرة & 3 & 0.92 & 3.93 & خلق بيئة تعليمية جاذبة للطلاب في المدرسة & 3 \\
\hline كبيرة & 4 & 0.94 & 3.91 & اهتمام المؤسسة التعليمية الكبرى بتطويروتحسين مخرجات التعليم & 7 \\
\hline كبيرة & 5 & 0.85 & 3.90 & إقامة مسابقات خاصة بمهارات القراءة المتنوعة للطلاب في المدرسة & 5 \\
\hline كبيرة & 6 & 1.04 & 3.83 & توفير مركز مصبادر تعلم متنوع ومشـوق في المدرسة & 4 \\
\hline كبيرة & 7 & 0.73 & 3.82 & توفير قاعات وفصيول ذكية وواسعة في المدرسة & 2 \\
\hline كبيرة & 8 & 0.53 & 3.81 & إقامة المؤسسة التعليمية الكبرى مسابقات تحفيزية كبرى خاصة بمهارات القراءة & 10 \\
\hline كبيرة & 9 & 0.64 & 3.80 & مراقبة المؤسسة التعليمية الكبرى لكل ما هو جديد في ميدان التعليم وخاصة بما & 9 \\
\hline كبيرة & 10 & 1.01 & 3.73 & توفّير المؤسسة التعليمية الكبرى لكل ما يحتاجه الطالب لعملية التعليم والتعلم & 6 \\
\hline كبيرة & & 0.53 & 3.89 & التصهورات المقترحة المتعلقة بدور المدرسة والمؤسسة التعليمية الكبرى & \\
\hline
\end{tabular}

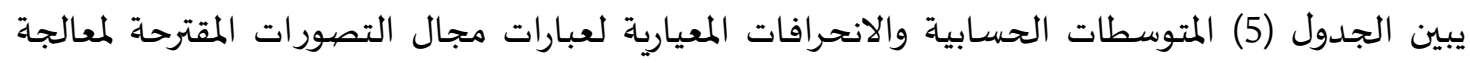

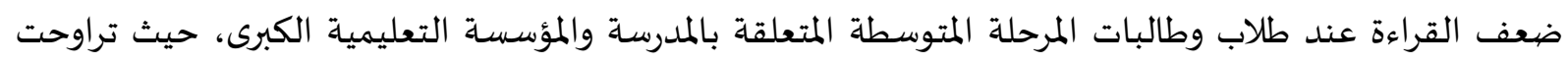

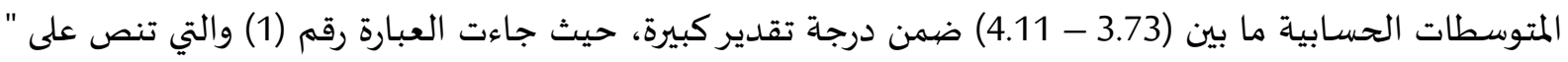

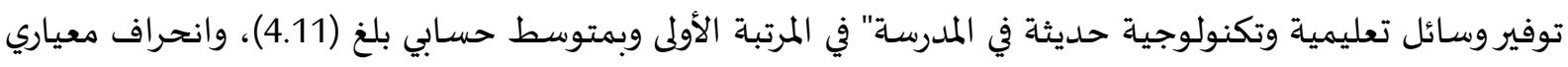

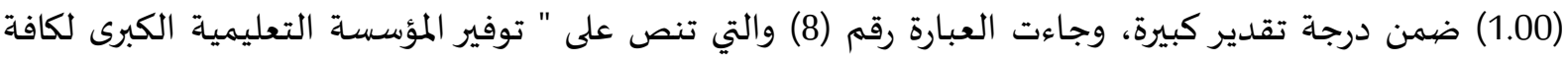

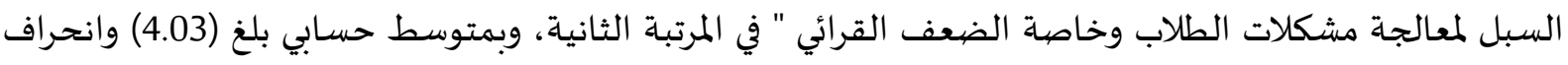


معياري (0.81) ضمن درجة تقدير كبيرة، بينما جاءت العبارة رقم (7) ونصها " توفيّر المؤسسة التعليمية الكبرى لكل

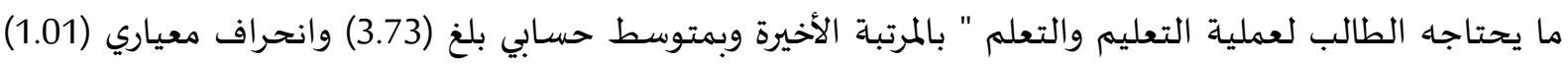

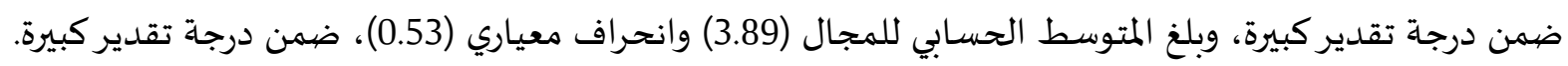

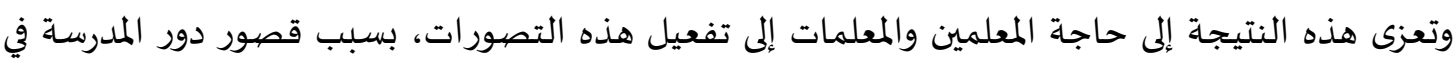
موضوع معالجاة ضعف القراءة عند الطلاب، حيث تفتقر الكثير من المدارس إلى توفير وسائل تعليمية وتكنولوجية المعاية

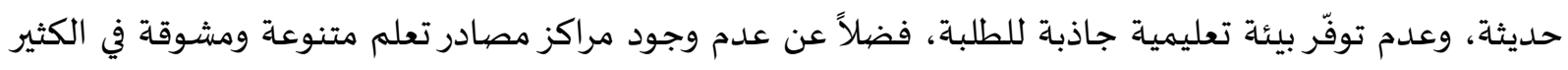

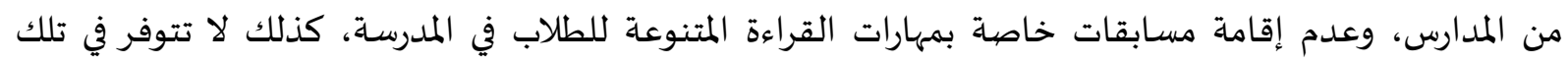
المدارس قاعات وفصهول ذكية وواسعة، وهذا يفسرسبب مجيء التصورات المقترحة في مجال المدرسة بدرجة كبيرة.

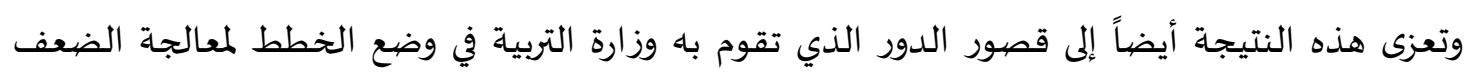

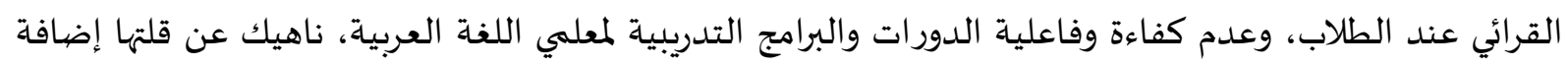

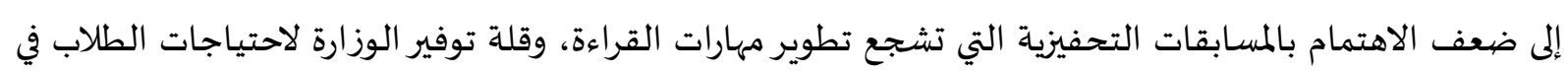

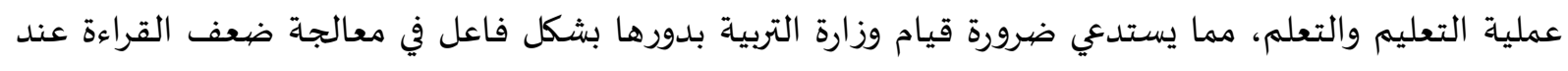

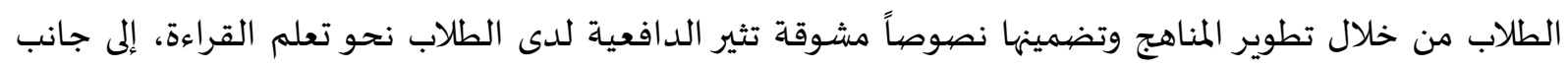
تفعيل دور التقويم الحقيقي، وعقد الدورات التدربيية للمعلمين. واتفقت هذه النتيجة مع نتيجة دراسة (UNESCO, 2019) التي بينت أن من أهم طرق تحسين معرفة

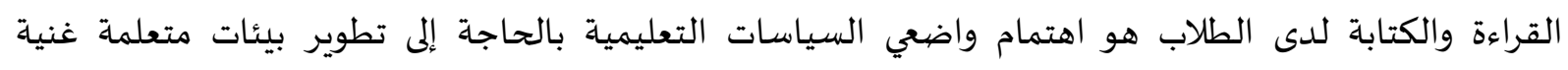

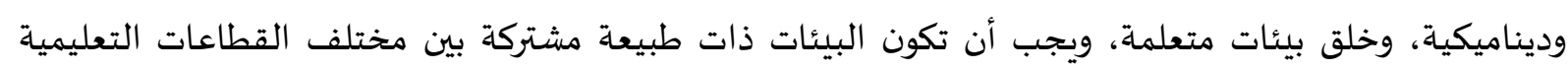
والمجتمعية.

النتائج المتعلقة بالسؤال الرابع: هل توجد فروق ذات دلالة إحصبائيا عند مستوى الدلالة (a =0.05)

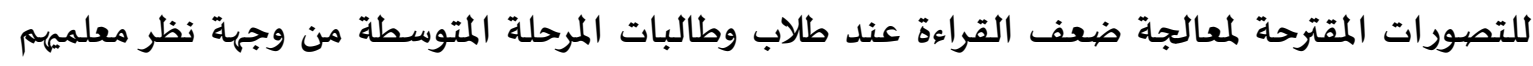

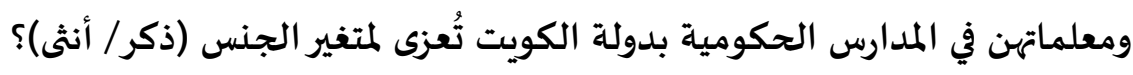

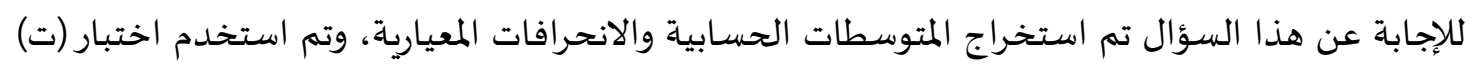

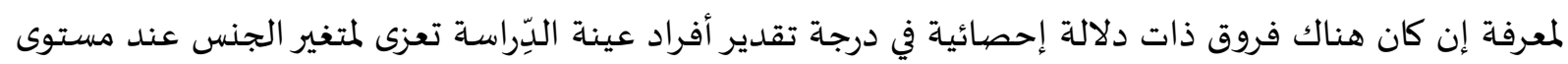

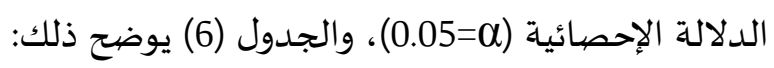
جدول (6) المتوسطات الحسابية والانحرافات المعيارية واختبار (ت) لاستجابات أفراتية أفراد عينة الدِّراسة على مجالات

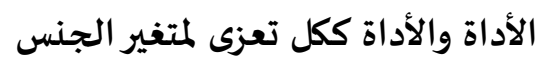

\begin{tabular}{|c|c|c|c|c|c|c|c|}
\hline 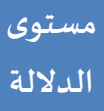 & قيمة ت & 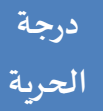 & المعياري - المراف & المتوسط الحسابي & العينة & الجنس & المجال \\
\hline \multirow{2}{*}{${ }^{*} 0.00$} & \multirow{2}{*}{5.861} & \multirow{2}{*}{348} & 0.44 & 4.07 & 183 & ذكر & \multirow{2}{*}{ التصهورات المتعلقة بدور الاسرة } \\
\hline & & & 0.57 & 3.75 & 167 & أنثى & \\
\hline \multirow{2}{*}{$*^{*} 0.00$} & \multirow{2}{*}{3.036} & \multirow{2}{*}{348} & 0.43 & 4.05 & 183 & ذكر & \multirow{2}{*}{ التصورات المتعلقة بدور التوجيه } \\
\hline & & & 0.35 & 3.79 & 167 & أنثى & \\
\hline \multirow{2}{*}{${ }^{*} 0.00$} & \multirow{2}{*}{4.703} & \multirow{2}{*}{348} & 0.52 & 4.01 & 183 & ذكر & \multirow{2}{*}{ التصوورات المتعلقة بدور المدرسة المبسة } \\
\hline & & & 0.51 & 3.75 & 167 & أنثى & \\
\hline
\end{tabular}


يُظهر الجدول (6) نتائج اختبار (ت) لدرجة تقدير أفراد عينة الدِّراسة نحو التصورات المقترحة لمعالجة ضعف القراءة عند طلاب وطالبات المرحلة المتوسطة من وجهة نظر معلميهم ومعلماتهن في المدارس الحكومية بدولة بلدية

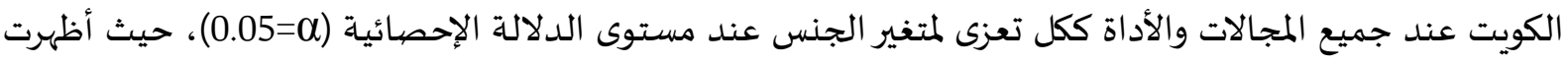

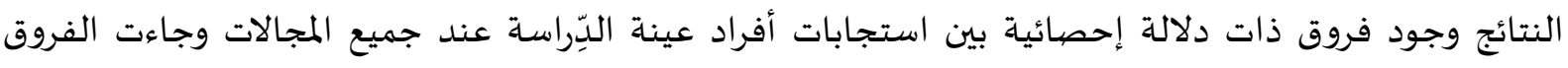

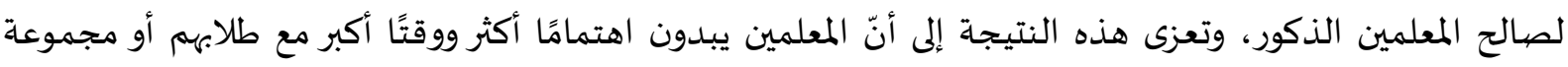
معينة منهم، وهذا على خلاف بعض المعلمات اللاتي يلجأن إلى محاباة طالباتهن نظراً لطبيعة المرأة واتسامها بالعاطفة، فيكون ذلك على حساب تعليمهن في بعض الأوقات.

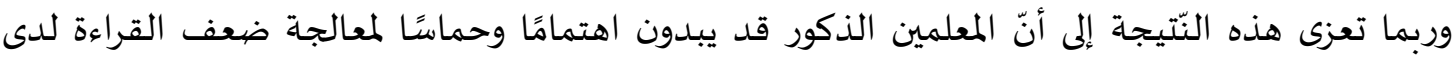

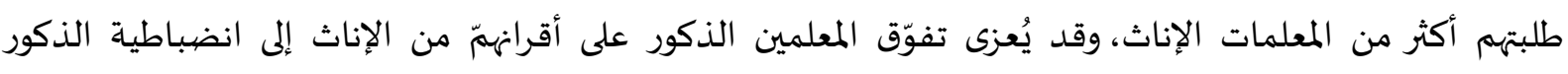

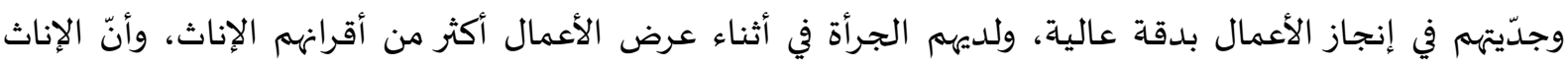
يظهرن قلقاً في أثناء التعامل مع الواجبات الاعمال بدفه والمهمّات الموكلة إليهن.

$$
\text { التوصيات والمقترحات }
$$

بناء على النتائج التي توصل إليها البحث، يوصي الباحث ويقترح بما يأتي:

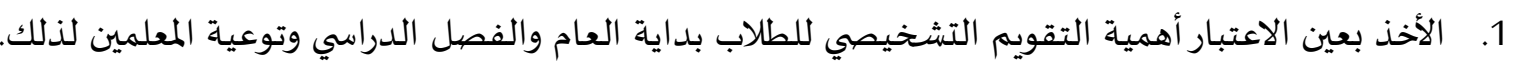

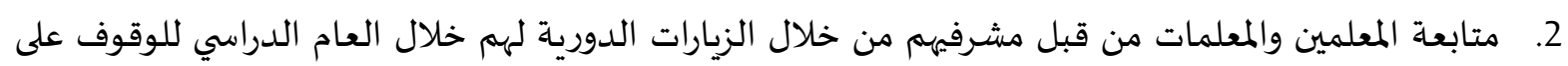

$$
\text { نقاط الضعف والقوة عند كل طالب وطالبة. }
$$

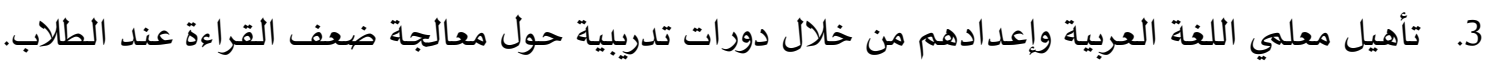

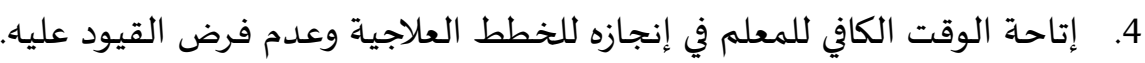
5. استمرار المدرسة بتقديم كافة السبل والخدمات التي تخدم إنجاز الخطط العلاجية المقدمة للطازلاب.

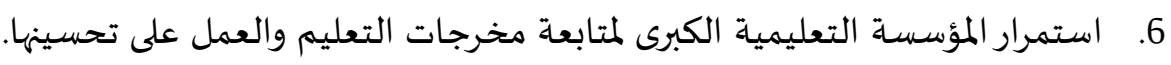
7. إيجاد حوافز معنوية للمعلمين مثل تخفيف النصاب التدريسي، وتبادل الزيارات الميدانية بين المعلمين لتبادل

$$
\text { 9. }
$$

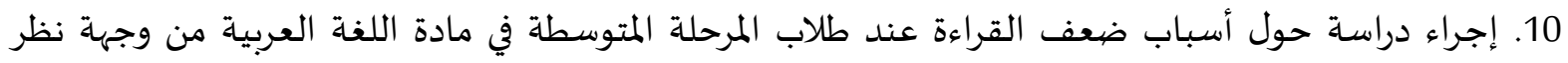

$$
\text { أولياء أمورهم. }
$$

11. إجراء دراسـة حول التصورات المقترحة لمعالجة ضعف القراءة عند طلاب وطالبات المرحلة الابتدائية من وجهة

$$
\text { نظر معلميهم ومعلماتهن متعلقة بمجالات محددة ومتعددة. }
$$


- أحمد، سناء (2019). أثر استخدام الاستراتيجية التذكرية لتعلم اللغة العربية في تحسين مهارات القراءة الجهرية

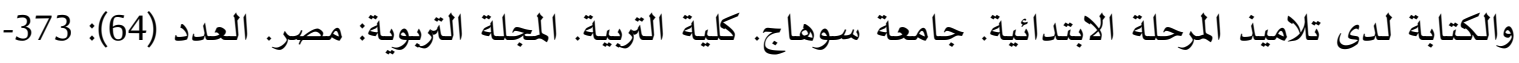

- - - - - -

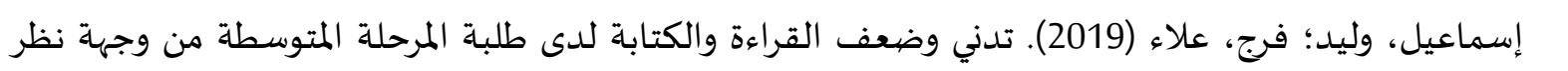

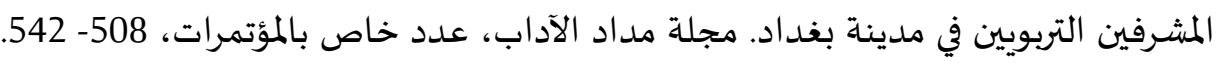

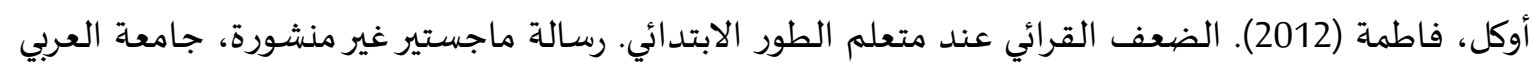
بن مهيدي أم البواقي، الجزائر. البجة، عبد الفتاح (2002). أصول تدريس العبية بين النظرية والتطبيق. عمان: دار الفكر للطباعة والنشر والتوزيع. بوخريصة، أسماء؛ زعطوط، حسين (2014). الضعف القرائي لدى تلاميذ المدرسة الابتدائية: أسبابه ومظاهره

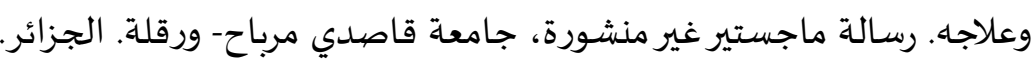

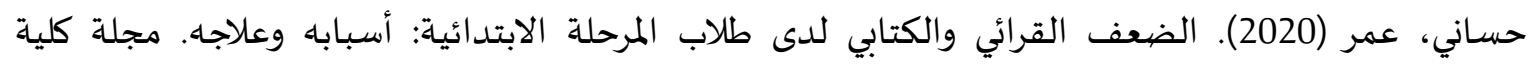
التربية. جامعة أسيوط. كلية التربية. 36(4): 115- 87. الخليفات، علي؛ الخليفات، أنوار (2020). أسباب الضعف القرائي لدى طلاب الصفوف الصوف الثلاثة الأولى من وجهة

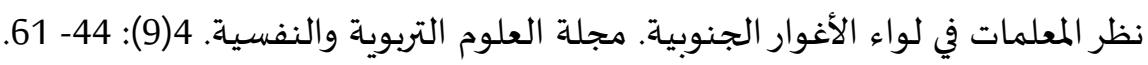

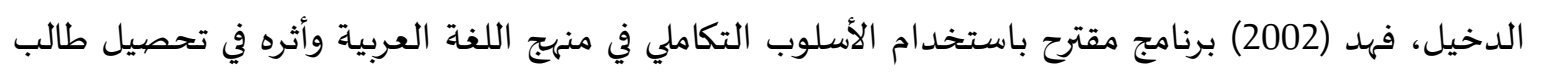
الصف الأول والمتوسط وإكسابهم للمهارات اللغوية في المملكة العربية. جامعة الإمام محمد بن سعود الإسلامية. الرياض. رقاني، زهراء (2017). الضعف القرائي لدى تلاميذ السنة الثالثة متوسط- دراسة ميدانية في متوسط أنجزمير، رسالة ماجستير غير منشورة، جامعة أحمد دراية أدرار. الجزائر.

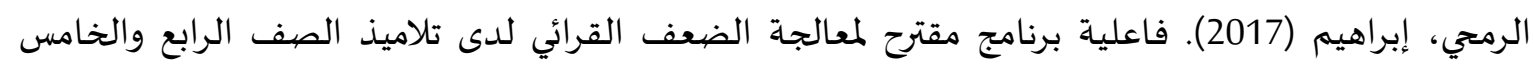

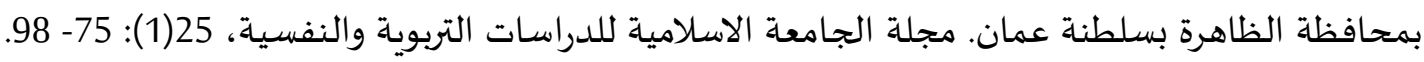
زايد، فهد (2013). أساليب تدريس اللغة العربية بين المهارة والصعوبة. عمان: دار اليازوري العلمية. زقوت، محمد (1999). المرشد في تدريس اللغة العربية. غزة: منشورات الجامعة الإسلامية.

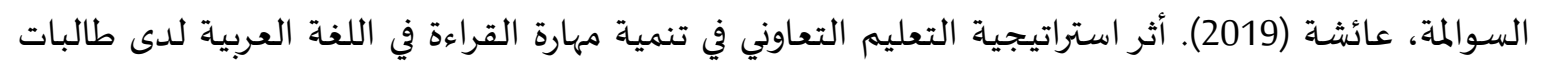

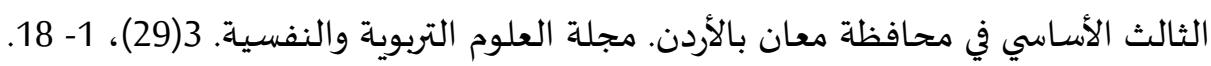

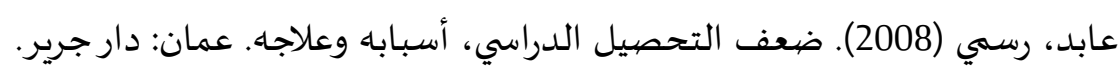

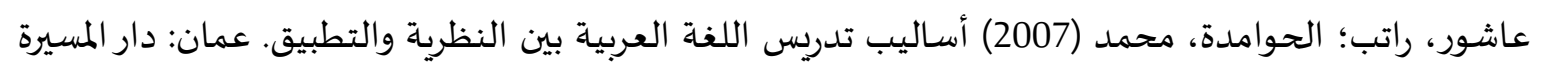
للطباعة والنشر. - عطية، محسن (2007). تدريس اللغة العربية في ضوء الكفايات الأدائية. عمان: دار المنهاج.

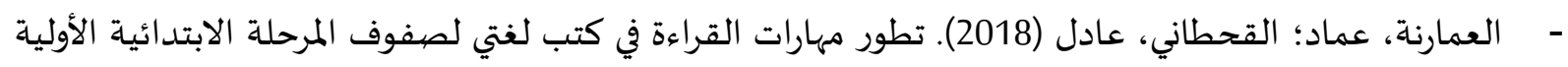
في المملكة العربية السعودية دراسة وصفية تحليلية. المجلة التربوية، جامعة سوهاج، العدد (53)، 227- 262 262. 
- القرعان، أسمهان (2018). مهارات القراءة لدى الطلبة العاديين وذوي صعوبات القراءة (الدسلكسيا) في الصف الرابع في المدارس الحكومية الأسـاسية في محافظة إربد: دراسة مقارنة. مجلة جامعة القدس المفتوحة للأبحاث والدراسات التربوية والنفسية. $9(25) ، ~ 136-149$. /https://www.almaany.com معجم المعاني الإلكتروني - موقع وزارة التربية دولة الكويت (2016). الوثيقة الأسـاسية للمرحلة المتوسطة. (motawaset.pdf (moedu.kw) - الهاشمي، عبد الله؛ البوسعيدي، فاطمة؛؛ الموسوي، علي؛ كاظم، علي؛ الخائفي، سالم (2016). مظاهر الضعف القرائي الشائعة لدى تلاميذ الحلقة الأولى من التعليم الأساسي بسلطنة عمان كما تراها معلمات المجال الأول. مجلة العلوم التربوية والنفسية (البحرين). 17(4): 473- 496.

\section{ثانياً - المراجع بالإنجليزية:}

- McCandliss, B, Beck, I L., Sandak, R, \& Perfetti C. (2013). Focusing Attention on Decoding for Children with Poor Reading Skills: Design and Preliminary Tests of the Word Building Intervention. Scientific Studies for Reading, 7 (1), 75- 104.

- Swerling, S, L. (2018). Common Types of Reading Problems and How to Help Children Who Have Them. The Reading Teacher, 69(5), 513- 522.

- $\quad$ UNESCO Institute for Lifelong Learning (2019). Fostering a culture of reading and writing - Examples of dynamic literate environments, Selected case studies from http://litbase.uil.unesco.org. 